\title{
Let's Twist Again: A High-Frequency Event-Study Analysis of Operation Twist and Its Implications for QE2
}

\begin{abstract}
This paper undertakes a modern event-study analysis of Operation Twist and uses its estimated effects to assess what should be expected for the recent policy of quantitative easing by the Federal Reserve, dubbed "QE2." The paper first shows that Operation Twist and QE2 are similar in magnitude. It then identifies six significant, discrete announcements in the course of Operation Twist that could have had a major effect on financial markets and shows that four did have statistically significant effects. The cumulative effect of these six announcements on longer-term Treasury yields is highly statistically significant but moderate, amounting to about 15 basis points (bp). This estimate is consistent both with time-series analysis undertaken not long after the event and with the lower end of empirical estimates of Treasury supply effects in the literature. The effects of Operation Twist on long-term agency and corporate bond yields are also statistically significant but smaller, about $13 \mathrm{bp}$ for agency securities and 2 to $4 \mathrm{bp}$ for corporates. Thus, the effects of Operation Twist seem to diminish substantially as one moves from Treasury securities toward private sector credit instruments.
\end{abstract}

\footnotetext{
$\mathrm{O}$ n December 16, 2008, the Federal Reserve's Federal Open Market Committee (FOMC) lowered the target for the interest rate on federal funds to essentially zero in response to the most severe U.S. financial crisis since the Great Depression. Since U.S. currency carries an interest rate of zero, it is virtually impossible for the FOMC to target a value for the federal funds rate that is substantially below zero. Faced with this zero lower bound, the FOMC in 2008 and 2009 endeavored to find alternative ways to stimulate the weak economy, such as by purchasing large quantities of mortgage-backed securities and longer-term Treasury securities in
} 
an effort to improve the functioning of those markets and reduce long-term interest rates. ${ }^{1}$

In late 2010, in response to continuing economic weakness and the zero lower bound, the FOMC embarked on a second round of quantitative policies, announcing its intention to purchase "a further $\$ 600$ billion of longer-term Treasury securities by the end of the second quarter of 2011."2 This program has become known in the financial community and the financial press as QE2.

The QE2 program has been controversial, with detractors conjecturing that the risks or costs of the policy are large while the benefits are small. For example, an open letter to Federal Reserve Chairman Ben Bernanke, signed by several prominent economists and published in full-page ads in the Wall Street Journal and the New York Times, asserted that the purchases "risk currency debasement and inflation" and could "distort financial markets"; the signatories said further, "we do not think they will achieve the Fed's objective of promoting employment" and that they are "neither warranted nor helpful in addressing either U.S. or global economic problems."

The present paper aims to estimate the potential benefits of QE2 by measuring the effect on long-term interest rates of Operation Twist, a very similar program undertaken by the Kennedy administration and the Federal Reserve in 1961. Although previous studies of Operation Twist using low-frequency (quarterly) data have generally found no significant effect of the program on long-term interest rates (see, for example, the exhaustive time-series analysis by Franco Modigliani and Richard Sutch 1966, 1967), the present paper undertakes a more modern, high-frequency event-study approach. The event-study methodology restricts attention to major announcements in the course of Operation Twist that can be pinpointed to a single day. By focusing on changes in Treasury yields

1. On November 25, 2008, the FOMC announced that it would purchase $\$ 500$ billion of mortgage-backed securities and $\$ 100$ billion of debt directly issued by the housingrelated government-sponsored enterprises (GSEs). On March 18, 2009, the FOMC announced that it would purchase an additional $\$ 750$ billion of mortgage-backed securities, an additional $\$ 100$ billion of GSE debt, and $\$ 300$ billion of longer-term Treasury securities. FOMC statements and minutes are available on the Federal Reserve Board's public website.

2. FOMC statement, November 3, 2010, available on the Federal Reserve Board's public website.

3. “An Open Letter to Ben Bernanke," Wall Street Journal, November 16, 2010, p. A17 (advertisement). Also available at www.economics21.org/commentary/e21s-openletterben-bernanke. 
in a narrow window of time surrounding each announcement, an event study holds other factors affecting the macroeconomic outlook constant, and thereby isolates the effects of the announcement itself on the yield curve. Lower-frequency time-series analyses must attempt to control for other factors affecting the yield curve directly, a procedure fraught with difficulties such as unobserved variables (financial market expectations of future interest rates and inflation), large residual errors, and endogeneity, as will be discussed in section II.

In contrast to Modigliani and Sutch, this paper finds that Operation Twist had a highly statistically significant effect on longer-term Treasury yields. However, consistent with Modigliani and Sutch's finding (1966, p. 196) that any effects of Operation Twist "are most unlikely to exceed some ten to twenty base points," this paper estimates that the size of these effects is moderate, with a cumulative effect on long-term Treasury yields of about 15 basis points (bp). This is also consistent with the lower end of Treasury supply effects estimated in the literature, discussed in section III. Finally, the paper examines to what extent the effects of Operation Twist spilled over to credit markets other than the Treasury market. It finds that longterm yields on government agency securities declined by almost as much as those on long-term Treasuries, but that long-term corporate bond yields declined by substantially less, only 2 to $4 \mathrm{bp}$. The paper presents evidence that this smaller effect is at least partly due to limited substitutability between corporate bonds and long-term Treasuries.

Operation Twist has several advantages over more recent episodes as a laboratory for estimating the likely effects of QE2. For example, estimates of the effects of the Federal Reserve's initial round of quantitative policies in 2008 and 2009-what some have called QE1—such as the studies by Joseph Gagnon and coauthors (2011) and Stefania D'Amico and Thomas King (2010), are subject to the concern that the 2008-09 financial crisis was a time of severe financial market disruption and low liquidity (see, for example, Gürkaynak and Wright 2011). The exceptionally poor functioning of financial markets during this period may have led Federal Reserve purchases to have an uncharacteristically large effect on markets. Thus, it is not clear that the effects of such purchases during QE1 are representative of the effects that one might expect in more normal times, such as the present environment in which QE2 is being conducted.

In addition, foreign governments have become increasingly large participants in the U.S. Treasury market over time: foreign official institutions now hold about $\$ 3.1$ trillion of U.S. Treasury securities-about one-third of the market—of which about $\$ 2.6$ trillion is held in longer-term Treasury 
notes and bonds. ${ }^{4}$ Foreign official purchases of U.S. Treasuries often vary by $\$ 100$ billion or more over the course of just a few months, responding to largely exogenous factors such as domestic economic developments and exchange rate interventions (Warnock and Warnock 2009). Francis Warnock and Veronica Warnock (2009) estimate that these purchases have a large effect on Treasury yields, implying that studies of Treasury supply effects using data since the 1980s must control for variation in foreign official purchases. An advantage of the Operation Twist period is that foreign government involvement in the U.S. Treasury market was so small that it can safely be ignored.

The paper proceeds as follows. Section I provides the historical context for Operation Twist and shows the remarkable similarities between that program and QE2. Section II describes the event-study methodology and the data. The effects of Operation Twist on Treasury yields are analyzed in section III. Section IV compares these results with those of previous studies. Section V investigates to what extent the effects of Operation Twist spilled over to markets other than the Treasury market. Section VI concludes.

\section{Operation Twist}

John F. Kennedy was elected president of the United States in November 1960 and inaugurated on January 20, 1961. The economy had been in recession since April of 1960; the recession would end in February 1961, although economic activity would remain weak for several months into the recovery. The incoming administration wanted to stimulate the economy with easier monetary as well as fiscal policy, but European interest rates were already higher than U.S. rates, leading to substantial flows of dollars and gold to Europe under the Bretton Woods fixed exchange rate system. The Federal Reserve (and the Kennedy administration) were very reluctant to lower short-term interest rates any further for fear of worsening the U.S. balance of payments and increasing the outflows of gold.

The Kennedy administration's proposed solution to this dilemma was to try to lower longer-term interest rates while keeping shorter-term interest rates unchanged. The idea was that business investment and

4. Data are for October 2010 and come from the Treasury's monthly "Major Foreign Holders of U.S. Treasury Securities," available at www.treasury.gov/resource-center/datachart-center/tic. 
housing demand were primarily determined by longer-term interest rates, whereas the balance of payments and gold flows were determined by cross-country arbitrageurs who acted on the basis of short-term interest rate differentials. ${ }^{5}$ If longer-term Treasury yields could be lowered without affecting short-term Treasury yields, the reasoning went, then investment could be stimulated without worsening the balance of payments and gold outflows. ${ }^{6}$

Thus, on February 2, 1961, Kennedy announced in a message to Congress a policy in which the Treasury and the Federal Reserve would cooperate to change the relative supplies of long-term and short-term Treasury securities in the open market. The Federal Reserve would maintain the current level of the federal funds rate but would buy longer-term Treasury securities to try to nudge longer-term interest rates lower. ${ }^{7}$ The Treasury meanwhile would reduce its issuance of longer-term notes and bonds and instead issue primarily short-term securities. ${ }^{8}$ At the time, this policy was referred to by Federal Reserve staff as "Operation Nudge," but in retrospect it has become known as "Operation Twist," in homage to the dance craze that swept the nation at about the same time (Meulendyke 1998, p. 39).

According to statistics from the Federal Reserve Bank of New York, the Federal Reserve ultimately purchased about $\$ 8.8$ billion of longer-term bonds as part of Operation Twist. ${ }^{9}$ Recent authors (for example, Gagnon and others 2011) have sometimes dismissed this program as being small, but in fact Operation Twist is comparable to QE2 relative to the size of the economy and the Treasury market. This is demonstrated in table 1,

5. The price of a Treasury bill is much less volatile than the price of a longer-term Treasury bond, making bills and other short-term debt a much more appealing vehicle for short-term arbitrage across currencies.

6. See "White House Sees Backing by FRB on Rate Policy," Wall Street Journal, February 3, 1961, p. 2, and "Kennedy Says FRB to Control Long-Term Rates," Wall Street Journal, February 9, 1961, p. 3.

7. Technically, the Federal Reserve in the late 1950s and early 1960s followed a policy of targeting the quantity of free reserves rather than the level of the federal funds rate (Friedman and Schwartz 1963, chapter 11). However, it was recognized that the federal funds rate varied inversely with the quantity of reserves, so for practical purposes this policy can be thought of as a loose federal funds rate target.

8. For additional details and discussion, see the Wall Street Journal articles cited in note 6 .

9. Meulendyke (1998). Over the same period, the Federal Reserve reduced its holdings of short-term Treasury bills by $\$ 7.4$ billion. For several years before Operation Twist, the Federal Reserve had subscribed to a "bills only" policy under which it bought no longer-term Treasury securities ("Reserve Is Buying Long Treasurys in Open Market in Policy Reversal," Wall Street Journal, February 21, 1961, p. 3.) 
Table 1. Comparing Operation Twist and QE2

Billions of current dollars except where stated otherwise

\begin{tabular}{lcr}
\hline & Operation Twist & QE2 \\
\hline Size of Federal Reserve program & 8.8 & 600 \\
GDP & 528 & 14,871 \\
Treasury marketable debt outstanding $^{\mathrm{a}}$ & 189.3 & 8,543 \\
Agency debt outstanding $^{\mathrm{b}}$ & 7.4 & 6,379 \\
Agency-guaranteed debt outstanding $^{\mathrm{c}}$ & 0.2 & 1,166 \\
Size of Federal Reserve program $_{\text {As percent of GDP }}$ & \\
$\quad$ As percent of Treasury debt outstanding & 1.7 & 4.0 \\
As percent of Treasury-guaranteed debt outstanding & 4.6 & 7.0 \\
Additional supporting program by Treasury? & & \\
\end{tabular}

Sources: Meulendyke (1998), U.S. Treasury Bureau of the Public Debt, Federal Reserve Flow of Funds, and Bureau of Economic Analysis.

a. Includes nominal and inflation-indexed Treasury securities in the hands of the public and excludes nonmarketable securities issued to the Social Security Administration, state and local governments, and households (savings bonds).

b. Primarily securities issued by Fannie Mae and Freddie Mac, which were implicitly (and later explicitly) guaranteed by the Treasury.

c. Primarily mortgage-backed securities. In 2010Q1 about \$4 trillion of mortgage-backed securities guaranteed by Fannie Mae and Freddie Mac were shifted directly onto the balance sheets of those agencies in the Flow of Funds. This reclassification does not affect the sum of U.S. agency debt and U.S. agencyguaranteed debt, but it has a large effect on the breakdown between these two categories.

d. During Operation Twist (but not QE2), the Treasury deliberately issued securities with shorter maturities than usual; the size of this shift is difficult to quantify but amounted to several billion dollars. See text for details.

which reports the nominal size of both programs along with nominal GDP and various measures of debt outstanding.

Although the debt of the U.S. agencies-the Federal National Mortgage Association (Fannie Mae), the Federal Home Loan Mortgage Corporation (Freddie Mac), the Federal Home Loan Banks, and a few smaller entitieswas not officially backed by the full faith and credit of the U.S. government, these agencies had close historical ties to the government, and their securities were widely viewed as having an implicit government guarantee. (That view was confirmed in September 2008, when the U.S. government placed Fannie and Freddie into receivership and explicitly guaranteed their debt obligations..$^{10}$ ) As a result, agency-issued and agency-backed securities have been, ex ante and ex post, close substitutes for U.S. Treasury securities.

10. The Treasury initially announced a capital injection into Fannie and Freddie of up to $\$ 100$ billion each. This guarantee was later doubled to $\$ 200$ billion each and then made unlimited in December 2009. 
As can be seen from table 1, the Federal Reserve's purchases of long-term Treasury securities during Operation Twist were roughly comparable to QE2 in several respects. First, Operation Twist was about half as large as QE2 relative to GDP-smaller, but similar enough in magnitude to be informative. Second, if changes in the supply of long-term Treasuries have any effect on long-term Treasury yields, then the initial quantity of long-term Treasury securities in the market, rather than the size of GDP, should be the relevant initial condition. This observation suggests that the total Treasury market would be a better benchmark for the size of each program, and by this metric Operation Twist was closer in size to QE2. Third, to the extent that agency and agency-guaranteed debt are close substitutes for Treasury securities, the relevant market arguably includes all three of these Treasury-guaranteed classes of assets. ${ }^{11}$ Relative to this market, Operation Twist was an even larger program than QE2.

Finally, a key feature of Operation Twist, emphasized by the Kennedy administration from the outset, was the joint participation by both the Federal Reserve and the Treasury. While the Federal Reserve was purchasing $\$ 8.8$ billion of longer-term Treasuries in the open market, the Treasury was actively supporting this policy by concentrating its issuance of new debt at shorter rather than longer maturities, by an amount that totaled at least several billion dollars. ${ }^{12}$ By contrast, QE2 has had no support from the Treasury (Hamilton and Wu forthcoming). ${ }^{13}$ Taking into account the Treasury as well as the Federal Reserve contribution to

11. One could extend this argument to all triple-A-rated debt securities, or even to all debt securities, but at each successive step the similarity of state-contingent payoffs to those of Treasury securities diminishes. Table 1 draws a line for the scope of the market at agency and agency-backed debt, since the substitutability of these securities for Treasuries is much greater and their state-contingent payoffs are much more similar to those of Treasuries than is the case for other types of debt.

12. For example, the issuance announced by the Treasury on February 2 (table 2) totaled $\$ 6.9$ billion. However, the Treasury's March 15 announcement revealed that its commitment to Operation Twist was only partial rather than full-see the discussion of that announcement in section II.B. Thus, it is difficult to come up with a more precise estimate of the size of the Treasury's participation in the program, other than that it amounted to several billion dollars.

13. In fact, during late 2010 and early 2011 the average duration of Treasury securities issued and outstanding both increased, directly counter to the goals of QE2 (Hamilton and $\mathrm{Wu}$ forthcoming). Thus, de facto, the effect of QE2 has been to partially offset the increase in supply of long-term securities coming from the Treasury. For purposes of this paper, the "effects of QE2" will refer to the effects of the policy relative to a benchmark in which there is no QE2 by the Federal Reserve-that is, taking the Treasury's increased issuance of long-term securities as given. 
Operation Twist, then, the former program appears to have been substantially larger than QE2. ${ }^{14}$

Operation Twist and QE2 are very similar qualitatively as well as quantitatively. In both episodes the Federal Reserve was unable or unwilling to lower its target for the federal funds rate-in the case of QE2 because of the zero lower bound on short-term rates, and in the case of Operation Twist because of a fear of increasing gold outflows that were already viewed as unacceptably large. Thus, the goal of both programs was to lower longerterm Treasury yields without lowering the federal funds rate. The methods used to implement each program are also very similar: for Operation Twist, the Federal Reserve and the Treasury essentially sold short-term Treasury bills and purchased longer-term Treasury notes and bonds. To implement QE2, the Federal Reserve is financing purchases of longer-term Treasuries by issuing bank reserves. Bank reserves are short-term liabilities of the Federal Reserve rather than of the Treasury, but aside from this technical distinction, the implementation of the two policies, Operation Twist and QE2, is essentially identical.

In summary, Operation Twist and QE2 are much more similar than has generally been appreciated. Nevertheless, there are notable differences between the two programs. First, Operation Twist was strongly endorsed by the Kennedy administration as well as the Federal Reserve, whereas QE2 has been backed only by the latter. Kennedy's strong support for Operation Twist also may have been interpreted by financial markets as a signal that the future course of fiscal as well as monetary policy would be more aggressive than expected; moreover, it suggested cooperation between the Treasury and the Federal Reserve that may have boosted financial market expectations regarding the overall size and aggressiveness of the program. In addition, monetary policy in the 1960s was less transparent than it is today, so the Federal Reserve's explicit endorsement of Operation Twist (discussed in section II.B) was more extraordinary and may have sent a stronger signal to the markets regarding the Federal Reserve's view of the program's importance.

These observations suggest that the effects of Operation Twist may have been even larger than what one might expect for QE2. Other differences between Operation Twist and QE2 include several background factors,

14. It is sometimes argued that QE2 was an "open-ended" policy, that the initial $\$ 600$ billion was expected to be only the first round, and thus that QE2 should be regarded as substantially larger than the initial figure would suggest. However, Operation Twist was also an open-ended policy, and it is not clear that it was expected to be any smaller than QE2, especially once the Treasury's participation in Operation Twist is taken into account. 
such as the difference in exchange rate regimes (fixed then, floating today), the fact that today's financial markets are more globally integrated, and the substantially worse long-term government budget outlook today than in the 1960s. However, it is less clear whether these background factors would increase or decrease the expected effectiveness of Operation Twist relative to QE2.

\section{Methods and Data}

Given the similarities between Operation Twist and QE2, it seems reasonable to use the former program to estimate the likely effects of the latter. However, previous studies of Operation Twist using lower-frequency regression methods, such as the exhaustive analysis by Modigliani and Sutch $(1966,1967)$ using quarterly data, have generally found no statistically significant effects. This section reexamines the episode using a high-frequency event-study approach.

\section{II.A. High-Frequency Event-Study Analysis}

A high-frequency event-study analysis uses changes in financial markets within narrow windows of time around major, discrete announcements to measure the effects of those announcements. Under the hypothesis of rational expectations in financial markets, asset prices should completely incorporate all information from a public announcement shortly after the announcement is made. In particular, studying the 1- or 2-day change in Treasury yields around a major macroeconomic announcement should be sufficient to provide an unbiased estimate of the complete effect of that announcement on the yield curve. Charles Jones, Owen Lamont, and Robin Lumsdaine (1998) and Michael Fleming and Eli Remolona (1999) provide evidence supporting this hypothesis, with no evidence of either "momentum" or "backtracking" in yields in the days following such announcements. ${ }^{15}$ Intuitively, it also seems reasonable that financial markets would not leave large profitable trading opportunities unexploited for more than a few hours, let alone 1 or 2 days, so long as the risks of those opportunities were not excessively large.

15. Although the finance literature has found evidence of over- or underreaction in some cases for small-capitalization stocks, such effects have not been documented for larger, more liquid markets such as the S\&P 500 or the Treasury market. Indeed, Jones and others (1998) and Fleming and Remolona (1999) provide evidence to the contrary for the Treasury market. 
There are several reasons to think that a high-frequency event-study analysis would be more powerful than lower-frequency time-series methods for detecting the effects of Operation Twist. First, longer-term Treasury yields are very sensitive to market expectations about macroeconomic variables such as inflation and the expected path of the federal funds rate. Unfortunately, these expectational variables can change quite dramatically from one quarter to the next and are unobserved by the econometrician, making them very difficult to incorporate into a regression framework. ${ }^{16}$ A high-frequency event-study analysis holds the macroeconomic outlook essentially constant by considering changes in yields across a 1- or 2-day window surrounding the announcement, during which the macroeconomic outlook changes very little except for the possible effects of the announcement itself. ${ }^{17}$

Second, the effects of Operation Twist may have been relatively small, on the order of 10 or 20 basis points, which is no bigger than the quarterly standard deviation of long-term Treasury yields. Modigliani and Sutch's (1966) quarterly regression model has a residual standard error of 9.3 basis points, which they characterize as "remarkably low" (p. 190) relative to the rest of the literature. Given the size of this standard error, it might be impossible to find statistically significant effects of Operation Twist in a low-frequency regression model even if the model is correctly specified and the size of those effects is correctly estimated. By contrast, daily changes in long-term interest rates average about 2 basis points, so it is much easier to determine whether a major announcement regarding Operation Twist had a statistically significant impact on long-term bond yields that day.

Finally, there is an endogeneity problem with monthly or quarterly interest rate data that can make obtaining structural or causal estimates of the effects of Operation Twist difficult, if not impossible. This is similar to the problem of identifying the effects of a monetary policy shock in a vector autoregression, which requires an identifying assumption to disentangle the effects of changes in interest rates on the macroeconomy from the effects of changes in the macroeconomy on interest rates (see,

16. One can try to control for expectations to some extent by using survey data; however, survey data do not exist for the Operation Twist period.

17. Of course, this requires that no other major macroeconomic data surprises or announcements occur on the same day as the announcement in which one is interested. For each of the identified announcements below, this assumption is verified from the bond market commentary for that day. 
for example, Christiano, Eichenbaum, and Evans 1999). Modigliani and Sutch $(1966,1967)$ estimated a reduced-form time-series model for long-term interest rates and then investigated to what extent changes in the relative supply of longer-term Treasury securities could explain the residuals of that reduced-form model. But if the Federal Reserve tended to step up its purchases of longer-term Treasuries whenever long-term interest rates started to rise- a plausible hypothesis - then Modigliani and Sutch's reducedform approach will be biased toward finding no effect of Federal Reserve purchases on longer-term yields, or even the perverse effect that such purchases caused longer-term yields to increase. A high-frequency eventstudy analysis avoids this endogeneity problem as long as each major announcement being considered was not a response to changes in long-term interest rates on that same day. ${ }^{18}$

For all of these reasons, then, an event-study approach offers many advantages over-or at least a worthwhile alternative to-low-frequency time-series analysis for estimating the effects of Operation Twist.

\section{II.B. Six Major Announcements}

To perform an event-study analysis of Operation Twist, one must first identify major announcements that carried significant news about the program and whose release can be pinpointed to a single day or two. For this study the ProQuest Historical Newspapers database was searched for all articles in the Wall Street Journal in 1961 and early 1962 that mentioned the Federal Reserve or the Treasury. ${ }^{19}$ This produced several hundred results. These articles and the Wall Street Journal's weekly bond market recaps were quickly read through to identify episodes related to Operation Twist - that is, the objective of lowering longer-term interest rates. This narrowed the number of relevant articles down to a few dozen. Of these, six were identified that, rather than rehashing the goals and methods of the program, represented major new announcements in the development of Operation Twist. These six announcements are summarized in table 2.

18. For more discussion of this point and an application of high-frequency methods to identify the effects of monetary policy shocks in a vector autoregression, see Faust, Swanson, and Wright (2004).

19. Unfortunately, a search for the phrase "Operation Twist" over this period yields no results because the program did not come to be known by that name until a few years later. Also, the widely used LexisNexis database does not cover news articles before 1977. 


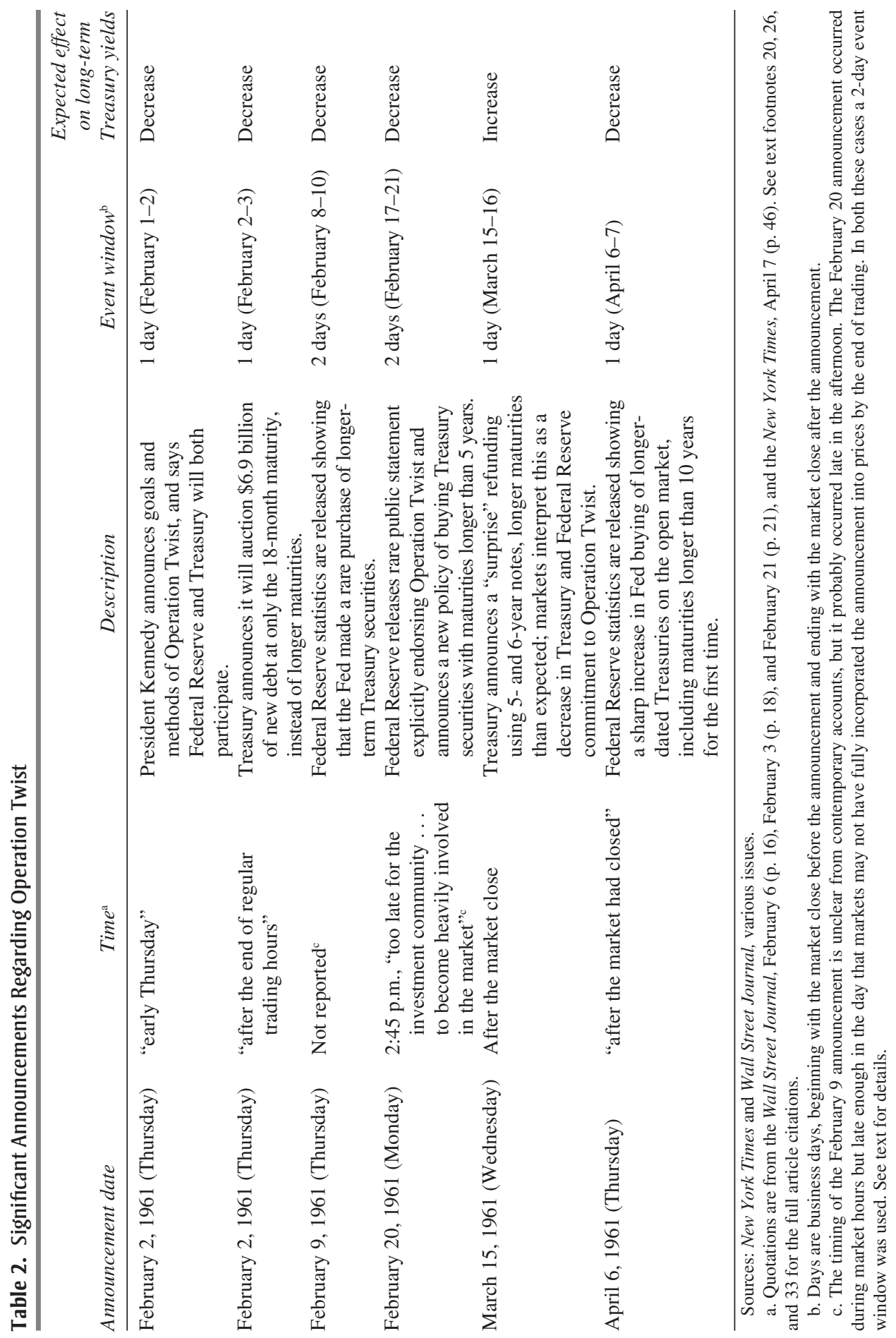


The first of these announcements is President Kennedy's introduction of the program on February 2, 1961. According to the Wall Street Journal, the announcement took place early in the day as part of an "economic message" to Congress, in which the president outlined the rationale, goals, and methods of Operation Twist and announced that the Federal Reserve would support the Treasury in its implementation. ${ }^{20}$ According to bond market commentary in the Wall Street Journal, the announcement had a significant impact on bond markets and was the main driver of bond yields that day. Because the announcement occurred early in the day, leaving plenty of time for markets to respond, a 1-day event window, from the market close on February 1 to the market close on February 2, is used here to measure the effects on Treasury yields.

A few hours after the president's message, "after the end of regular trading hours," the Treasury declared that its upcoming refunding of $\$ 6.9$ billion of Treasury debt would be concentrated entirely at the 18-month maturity, instead of longer maturities. ${ }^{21}$ The announcement was obviously intended to bolster the president's introduction of Operation Twist earlier in the day, but the size and complete concentration of the refunding at shorter maturities may have been a surprise to financial markets and could have created additional follow-on effects on bond yields the next day. Because the announcement occurred after the close of trading on February 2, a 1-day event window, from the market close on February 2 to the market close on February 3, is again used to measure the effects.

Several days later, on February 9, the Federal Reserve released its weekly breakdown of Treasury security holdings by maturity for the week

20. This economic message should not be confused with the Economic Report of the President of that year, which was released by President Eisenhower on January 18. Kennedy's economic message announced and outlined Operation Twist, and the details were subsequently filled in by administration officials in conversations with reporters. Although the economic message contained other economic proposals, such as a temporary extension of unemployment benefits, many of these other proposals had been anticipated by Kennedy's January 30 State of the Union Address, executive orders, and speeches. Contemporary accounts in the Wall Street Journal focus almost entirely on Operation Twist, so there appears to have been little else in the message of comparable interest to financial markets. See "White House Sees Backing by FRB on Rate Policy," Wall Street Journal, February 3, 1961, p. 2; "Treasurys, Prime Corporates Advance as Trading Picks Up," Wall Street Journal, February 3, 1961, p. 18; and "The Bond Markets: Top-Grade Corporates, Treasurys Up in Week As Trading Increased," Wall Street Journal, February 6, 1961, p. 16. For the texts of Kennedy's economic message, State of the Union Address, and executive orders, see Woolley and Peters (2010).

21. The articles describing this announcement are the same as for the previous announcement. The quotation is from "Treasurys, Prime Corporates Advance as Trading Picks Up," Wall Street Journal, February 3, 1961, p. 18. 
ended Wednesday, February 8 . The report showed that the Federal Reserve had made a rare addition to its holdings of longer-term Treasury securities during the week, which was noteworthy because for the previous 10 years the Federal Reserve had followed a "bills-only" policy, purchasing only Treasury bills with 12 months or less to maturity, except in the event of a substantial disruption in longer-term Treasury markets. ${ }^{22}$ Although the purchase was not particularly large and the average maturity of the purchased securities was not very long (just over 1 year), it was a clear departure from the bills-only policy and the first signal from the Federal Reserve (as opposed to the administration) that it was at least tentatively supporting Operation Twist. ${ }^{23}$ The intraday timing of the February 9 statistical release is not reported by either the Wall Street Journal or the New York Times, but other such releases were typically made late in the day (see, for example, the April 6 announcement below). Since the timing of this release is unclear, a 2-day event window, from the market close on February 8 to the market close on February 10, is used to measure its impact. $^{24}$

The Federal Reserve dramatically increased its commitment to Operation Twist a few days later, on February 20, 1961. That afternoon, the FOMC released what was in those days an extremely rare public statement, describing a change in its government bond-buying policy. The announcement read, in part,

During recent years, transactions for the system account, except in correction of disorderly markets, have been made in short-term U.S. Government securities. Authority for transactions in securities of longer maturity has been granted by the open market committee of the Federal Reserve System in the light of conditions that have developed in the domestic economy and in the U.S. balance of payments with other countries. ${ }^{25}$

22. For more discussion of the Federal Reserve's bills-only policy, see "Reserve Is Buying Long Treasurys in Open Market in Policy Reversal," Wall Street Journal, February 21, 1961, p. 3.

23. For example, the Wall Street Journal ("Reserve Board Raises Long-Term Treasury Holdings," February 10, 1961, p. 6) reported that "the Kennedy Administration has been seeking the cooperation of the Federal Reserve Board to bring down long-term interest rates," but that "the Federal Reserve has not said whether it plans any change in its open-market operations to nudge long-term rates downward."

24. Given the timing of the April 6 announcement, it is very likely that the February 9 announcement also occurred after the market close. The 2-day window used here is on the conservative side, but using a 1-day window would make essentially no difference in the results (see table 3).

25. "Reserve Is Buying Long Treasurys in Open Market in Policy Reversal," Wall Street Journal, February 21, 1961, p. 3. 
The release also explicitly extended the scope of Federal Reserve purchases of Treasury securities to maturities greater than 5 years. ${ }^{26}$ The announcement was striking, both for the manner of its release and because of its clear endorsement of the goals and methods of Operation Twist. Any previous doubts about the degree to which the Federal Reserve was committed to the Kennedy administration's program would have been immediately dispelled with this announcement.

The Federal Reserve's statement was released at 2:45 p.m., reportedly "too late for the investment community at large to become heavily involved in the market." ${ }^{27}$ Thus, a 2-day event window is used for this announcement, from the market close on Friday, February 17, to the market close on Tuesday, February 21.

The four announcements above each signaled an increasing degree of commitment by the Treasury or the Federal Reserve to Operation Twist. In contrast, a Treasury announcement on March 15, 1961, was perceived by financial markets as a decreased degree of commitment to the program. After the markets closed that afternoon, the Treasury announced an advance debt refunding operation, in which an offer is made to exchange soon-tomature Treasury securities for newly issued, longer-maturity Treasuries. ${ }^{28}$ The refunding itself was not so much a surprise as were the timing of the announcement (during Operation Twist) and the length of the debt maturities being offered in exchange ( 5 and 6 years). As reported by the New York Times, "Market circles had expected that the advance refunding device... would be used by the Treasury again, but not so soon, and especially not while the Federal Reserve System was engaged in a market operation ...

26. "Reserve Is Buying Long Treasurys in Open Market in Policy Reversal," Wall Street Journal, February 21, 1961, p. 3, and "Long Treasurys Show Gains, Top-Quality Corporates Up a Bit," Wall Street Journal, February 21, 1961, p. 21. A few days later, on February 23, the Federal Reserve's weekly balance sheet report confirmed that it had purchased a significant quantity of such securities. However, these purchases were not a surprise given the February 20 statement ("FRB Last Week Bought Treasurys in 5-10 Year Range," Wall Street Journal, February 24, 1961, p. 6), and therefore the February 23 report is not included among the announcements in table 2.

27. "Long Treasurys Show Gains, Top-Quality Corporates Up a Bit," Wall Street Journal, February 21,1961, p. 21 . In the early 1960 s, government securities trading desks typically closed at 3:30 p.m. Moreover, daily quotation sheets distributed to clients and newspapers typically were based on 2:30 p.m. price quotations, so it is unclear whether any effects of the Federal Reserve's 2:45 p.m. announcement are reflected in the market quotations for February 20. See Scott (1965, chapter 3) for more details.

28. Paul Heffernan, "Bonds: Treasury Bills Firm as Other Gilt-Edge Issues Show Declines," New York Times, March 16, 1961, p. 56. 
aimed at reducing long-term interest rates." ${ }^{29}$ According to the Wall Street Journal, "Some interpreted the advance refunding as indicating a change of thinking by the Treasury and the Federal Reserve System," in particular that it "may mean the monetary authorities, including the Federal Reserve, are satisfied with prices and rates prevailing in the bond market [and] may believe that business in general is on the road to recovery." ${ }^{30}$ James Tobin, a member of Kennedy's Council of Economic Advisers in 1961, is said to have been "furious" with the Treasury for this announcement. ${ }^{31}$ The expected effect of the announcement on long-term Treasury yields is thus opposite to the effects of the first four announcements. Because the announcement was made after the market close, a 1-day event window is used here to measure its effects, from the market close on March 15 to the market close on March 16.

The sixth and final major announcement regarding Operation Twist during 1961 and 1962 occurred on April 6, 1961, and again involves a weekly statistical release by the Federal Reserve. The release showed a substantial increase in the Federal Reserve's holdings of longer-term Treasury securities for the week ending Wednesday, April 5, and in particular its first purchase in many years of Treasury bonds with greater than 10 years to maturity. These purchases provided renewed confirmation of the Federal Reserve's commitment to Operation Twist and were reported as such by the press. ${ }^{32}$ The statistical release occurred "after the market

29. Paul Heffernan, "Bonds: Prices for Most Issues Decline in Light Trading," New York Times, March 17, 1961, p. 48.

30. "Bond Markets: Treasurys Led Week's Drop; Top Corporates Fell as Much as 1/2-Point," Wall Street Journal, March 20, 1961, p. 20. The market's interpretation of Treasury's announcement was at least partly correct: Treasury staff had decided that new Treasury issuance would continue to focus on short maturities (consistent with Operation Twist) but that refundings of outstanding Treasury debt would continue to take place at long maturities (Wall Street Journal, "Treasury to Offer New 3 5/8\%, 3 3/8\% Bonds for Swap," March 16, 1961, p. 4). The thinking behind this policy, according to the Journal, was that holders of outstanding Treasury debt would roll their debt over anyway, so that issuing longer-term securities to these investors would not affect the spread between long- and short-term yields and thus would not interfere with Operation Twist. However, the market reaction to the Treasury announcement suggests that this policy may have been misguided and counterproductive. Thus, after the March 15 announcement, one could reasonably characterize the Treasury as being partially rather than fully committed to Operation Twist.

31. Richard N. Cooper, comment during the general discussion of this paper at the Brookings Papers conference. Cooper was a senior staff economist at the Council of Economic Advisers in 1961.

32. "Reserve System Steps Up Buying of Federal Issues," Wall Street Journal, April 7, 1961, p. 4, and "The Bond Markets: High-Grade Corporates Eased; Treasurys Were Mixed in Slow Week," Wall Street Journal, April 10, 1961, p. 17. 
had closed, ${ }^{33}$ and so a 1-day event window is used for this announcement, from the market close on Thursday, April 6, to the market close on Friday, April 7.

For each of these six announcements, data on Treasury market closing prices were collected from the "Government Securities" column of the Wall Street Journal for the business days surrounding the announcement. ${ }^{34}$ (Daily yield curve data are available in electronic format from the Federal Reserve Board and other sources only from 1962 onward.) For this study the focus was on collecting data for a wide range of maturities that accurately characterize the yield curve at both the short and the long ends; in particular, data were collected on Treasury securities with 3 months and $1,2,5,10$, and 30 years remaining to maturity. To reduce the influence of idiosyncratic changes in price for any single Treasury security on the results, the average yield to maturity of the three Treasury securities closest to the target maturity was computed for each maturity listed above. $^{35}$

\section{II.C. Hypothesis Tests}

The null hypothesis for this analysis is that Operation Twist announcements had no effect on Treasury yields at any maturity. Under the alternative hypothesis, there are two main channels through which the announcements in table 2 might have affected yields. First, there is the direct effect of changes in the expected supply of long-term Treasuries on yields: A reduction in the net supply - through either a decrease in Treasury issuance or an increase in Federal Reserve purchases-should cause long-term Treasury yields to

33. Paul Heffernan, "Bonds: U.S. Issues Score Their First Good Gain in a Month," New York Times, April 7, 1961, p. 46.

34. These reported yields come from quotation sheets distributed by Treasury market dealers, which, as discussed above, were typically based on 2:30 p.m. price quotations; thus, they do not correspond exactly to the $3: 30 \mathrm{p} . \mathrm{m}$. closing prices in the market (Scott 1965). However, they would typically be very close to the closing prices and will be referred to here as closing prices for expositional convenience. Also, in a few cases (March 15-16 and April 7), data from the Wall Street Journal were unavailable or illegible, in which case Treasury yields for the same securities as reported by the New York Times were used.

35. Callable bonds (which are quoted with a range of maturity dates spanning several years) were excluded from the analysis to ensure that the maturities of all bonds are accurately measured and that the price is free from any implicit option premia associated with callability. At the 5-year maturity, there were only two noncallable securities with close to 5 years remaining to maturity, so those two rather than three securities were used to measure yields at that maturity. 
fall. ${ }^{36} \mathrm{In}$ addition, the announcements in table 2 may have been interpreted by financial markets as signals about the future course of monetary or fiscal policy. For example, markets may have interpreted announcements by the Federal Reserve that it was supporting Operation Twist as a signal that the federal funds rate also would be held at its then low level for a greater length of time. ${ }^{37}$ Similarly, Kennedy's announcement of Operation Twist may have signaled that the new administration would be more aggressive and imaginative than expected with respect to stimulating the economy, which may have led to increased expectations of fiscal stimulus.

In contrast to Treasury supply effects, the response of long-term Treasury yields to the signals described above does not have a clear sign prediction. For example, increased expectations of fiscal stimulus would tend to cause longer-term interest rates to rise, while expectations of easier monetary policy could conceivably cause longer-term nominal interest rates to either rise or fall. However, given the Federal Reserve and the administration's stated commitment to lowering long-term Treasury yields, the net effect of Operation Twist announcements, under the alternative hypothesis, should be to cause longer-term Treasury yields to decrease. A similar line of reasoning implies that announcements relating to Operation Twist, under the alternative hypothesis, should cause short-term Treasury yields to increase or stay the same. ${ }^{38}$ Short-term interest rates should not fall, because the Federal Reserve and the administration were committed to preventing such a decline out of concern about gold outflows.

36. This sign prediction follows from the assumption of a downward-sloping demand curve for long-term Treasuries: as the available quantity decreases, the equilibrium price should increase and the yield to maturity should fall. Greenwood and Vayanos (2008) and Vayanos and Vila (2009) provide a formal model with preferred-habitat investors and risk-averse arbitrageurs that implies a downward-sloping demand curve for Treasury securities of each maturity. Note that this modeling framework is arbitrage-free, so that the alternative hypothesis does not require an assumption of irrational expectations or arbitrage opportunities.

37. As discussed in note 7, the Federal Reserve targeted a measure of reserves rather than the federal funds rate during this period, but for practical purposes and expositional convenience this policy can be thought of as a loose federal funds rate target.

38. President Kennedy and the Treasury gave no indication that the total quantity of Treasury issuance would change under Operation Twist, only its composition. Thus, the Treasury's issuance of short-term securities would have to increase, which would push shortterm Treasury yields upward under the alternative. Signals about the future course of fiscal policy would also tend to push yields upward, although this might be offset to some extent by signals about easier monetary policy in the future. However, even under the alternative hypothesis, short-term Treasury yields could remain unchanged if the Federal Reserve maintained a constant target for the federal funds rate, since those yields are closely linked to the funds rate. 
To estimate the effects of Operation Twist, one would ideally like to have data on financial market expectations regarding the net supply of long-term bonds and the paths of fiscal and monetary policy both before and after each announcement in table 2, in order to measure the change in market expectations attributable to each announcement. Unfortunately, no such data exist. Nevertheless, one can test the null hypothesis by measuring the change in yields across each announcement and determining whether and to what extent the change is statistically significant - that is, how large it is relative to the unconditional standard deviation of Treasury yieldsand whether it is in the direction predicted by the alternative hypothesis. If the announcements consistently lead to significant effects in the predicted direction, one would reject the null hypothesis and turn to the question of estimating the total size of the effects of Operation Twist.

Finally, note that five of the six announcements in table 2 represent a perceived increase in the commitment of the Kennedy administration, the Treasury, or the Federal Reserve to Operation Twist. Each of these five announcements thus should have led to a decrease in long-term Treasury yields under the alternative. By contrast, the March 15 announcement was seen as a decrease in the commitment of the Treasury (and perhaps also of the Federal Reserve) to the program and thus should have led to an increase in long-term Treasury yields.

\section{The Response of Treasury Yields to Operation Twist}

The results of the event-study analysis described above are summarized in table 3. The top panel reports Treasury yields at the market close on each day of every event window in the sample. The second panel reports the change in Treasury yields across the event window for each announcement. The bottom panel reports the unconditional standard deviation of Treasury yield changes over 1- and 2-day windows as benchmarks for comparison. ${ }^{39}$

The statistical significance of each Treasury yield response in the table is assessed relative to the unconditional standard deviation for the same maturity and window size in the bottom panel. Statistical significance for

39. The 6- and 8-day changes are discussed below. Unconditional standard deviations are computed for 1962 rather than 1961 for two reasons: First, daily data on Treasury yields are available from the Federal Reserve Board beginning on January 2, 1962, but not before. Second, ideally one would compute an unconditional standard deviation that is not unduly influenced by Operation Twist itself, and 1962 largely postdates the Operation Twist period. The unconditional standard deviations of Treasury yield changes in 1963 and in 1964 are less than in 1962, so our measure of standard deviation here is conservatively large. 


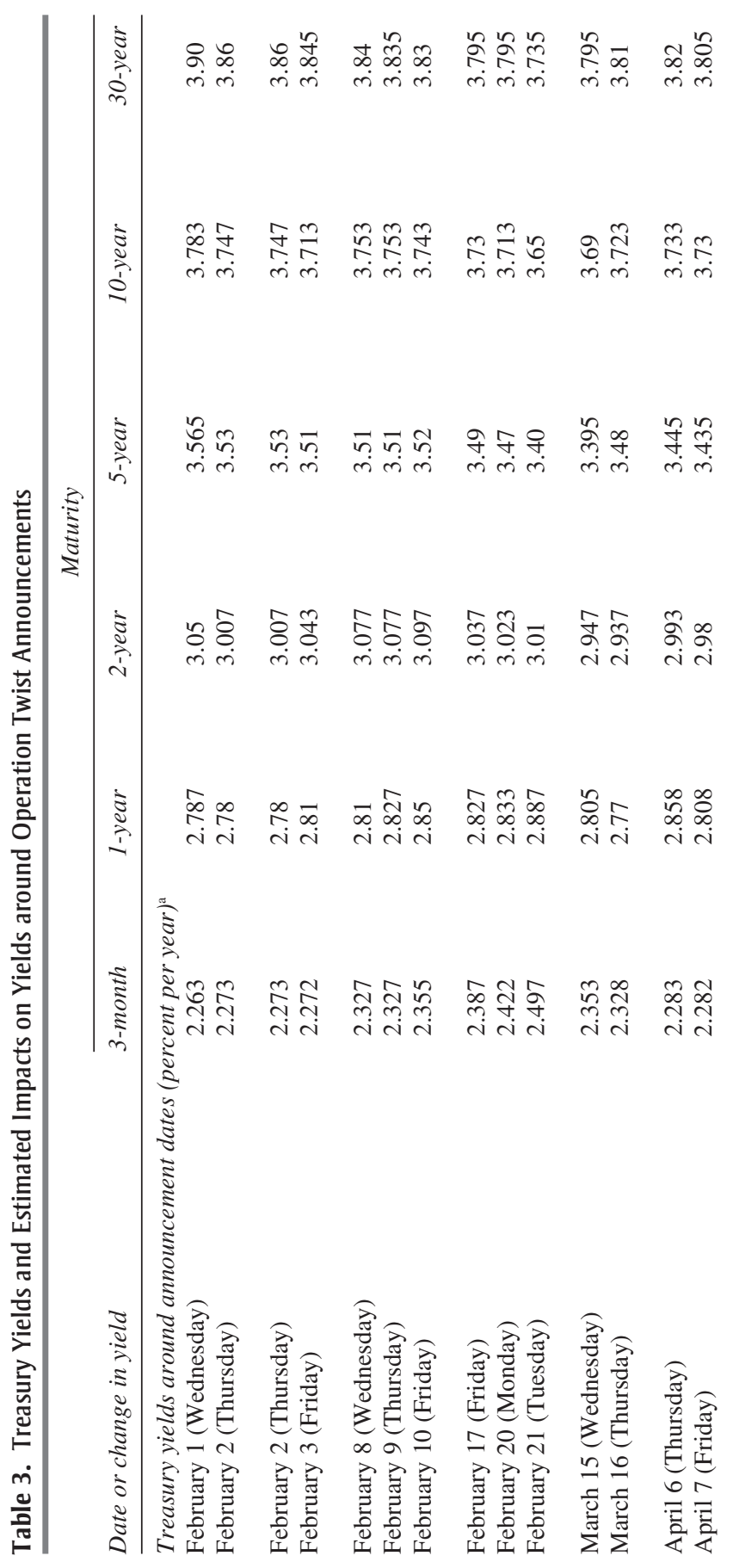




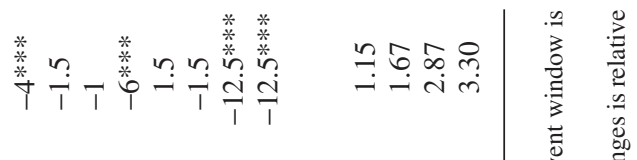

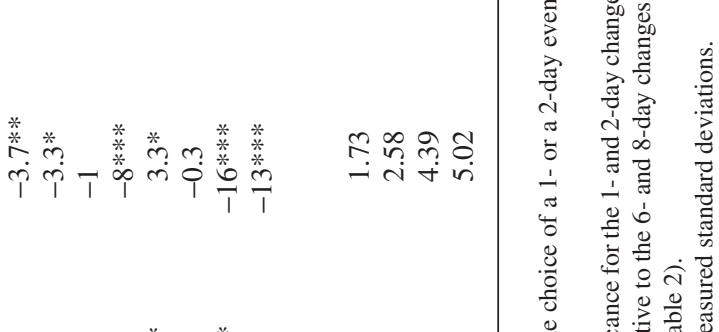

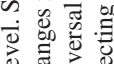

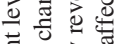

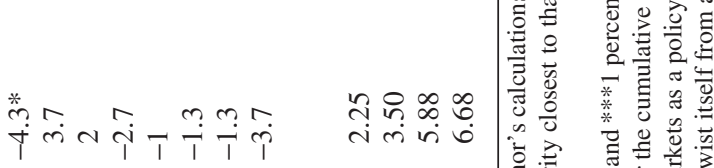

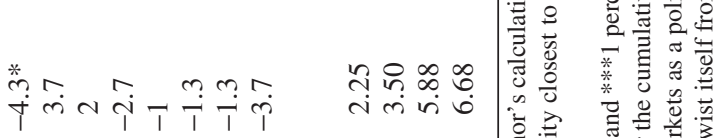

$$
\begin{aligned}
& \exists \cong \frac{0}{0} \\
& \text { 苛善光 }
\end{aligned}
$$

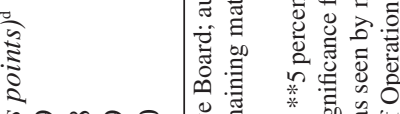

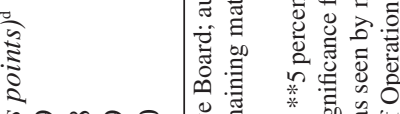

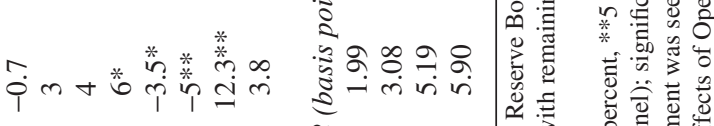

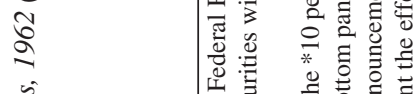

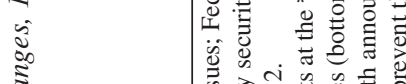

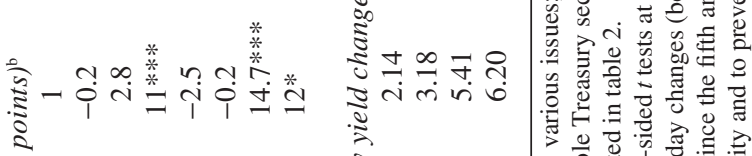

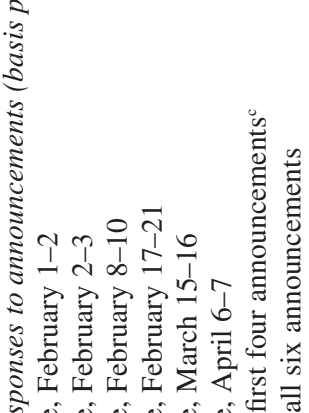

$$
\begin{aligned}
& \text { S. }
\end{aligned}
$$

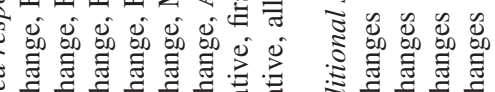

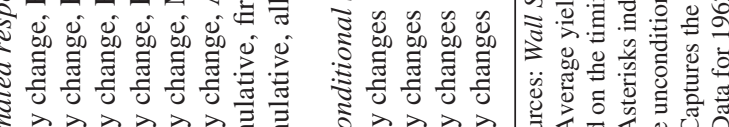

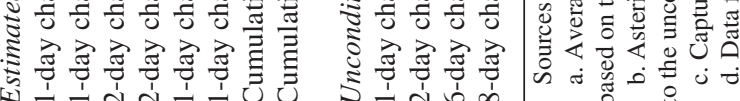

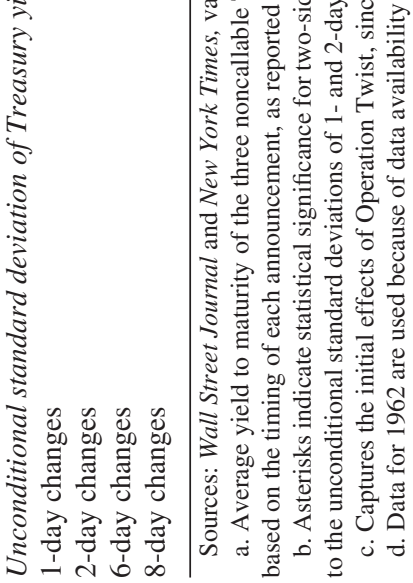


a $t w o$-sided $t$ test is reported, even though the alternative hypothesis provides clear sign predictions for the shortest and longest maturities; this is done both to minimize confusion (since the one-sided tests go in opposite directions for short and long maturities and have no clear sign prediction at the intermediate, 2-year maturity) and to avoid the appearance of overstating the significance of the results in the table. The discussion of statistical significance in the text will also refer to two-sided $t$ tests by default and will explicitly discuss the results of a one-sided $t$ test only when they are interesting.

Of the six announcements in table 3, the Federal Reserve's endorsement of Operation Twist on February 20 shows the most remarkable effect. Treasury yields with 5 or more years to maturity fell by 6 to $9 \mathrm{bp}$; this effect is highly statistically significant, with $t$ statistics in excess of 3 . But what makes these movements even more striking is the response of 3-month and 1-year Treasury yields, which simultaneously rose by 11 and $6 \mathrm{bp}$, respectively, with the former statistically significant at the 1 percent level and the latter at the 5 percent level for a one-sided test in the direction of the alternative. The Wald statistic for the joint movement of all six Treasury yields during this 2-day window is 53.5 , corresponding to a $p$ value of less than $10^{-9}$. Moreover, the yield curve response is completely consistent with the alternative hypothesis and thus raises serious questions about the validity of the null.

President Kennedy's introduction of Operation Twist on February 2 is almost as interesting. Longer-term yields fell by about 4 bp that day, while short-term yields were about unchanged. The 10- and 30-year yield responses are significant at the 5 percent level or better, and the 5-year yield response is significant at the 5 percent level for a one-sided test in the direction of the alternative. The Wald statistic for the joint change in yields is 16.6 , with a $p$ value of 1.1 percent, and the change is in the direction predicted by the alternative.

The response to the Treasury's announcement after the market close on February 2 is not as strong as for the Federal Reserve's and the president's announcements just discussed; nevertheless, the changes in the 10-, 30-, and 1-year Treasury yields are all statistically significant at the 10 percent level or better for one-sided tests in the directions predicted by the alternative (downward for the 10- and 30-year yields, upward for the 1-year yield). The Wald statistic for the joint change in yields is 28.6, even larger than for Kennedy's announcement, because of the stronger upward "twist" at the 1- and 2-year maturities, a more unusual pattern. The $p$ value for this move is less than $10^{-4}$, and it is again in the direction predicted by the alternative. 
The Treasury's surprise refunding announcement on March 15 is the one announcement in the sample that was perceived as a decrease in the government's commitment to Operation Twist. Thus, the alternative hypothesis predicts that long-term interest rates should have increased in response to that announcement. In fact, this is what the data show, particularly at the 5-year maturity, which was precisely the maturity at which the Treasury announced that the new supply would be forthcoming. Yields for that maturity rose by $8.5 \mathrm{bp}$, with a $t$ statistic of more than 4 , but the increases at the 10- and 30-year maturities are also statistically significant at the 5 and 10 percent levels, respectively, for a one-sided test in the direction of the alternative. At the same time, short-term yields twisted downward by 2.5 to $3.5 \mathrm{bp}$, and the response of the 1-year yield is significant at the 5 percent level for a one-sided test. The Wald statistic for the joint movement of yields is 73.5 , with a $p$ value of less than $10^{-13}$, and this movement is in the direction predicted by the alternative.

Finally, the Federal Reserve's statistical releases on February 9 and April 6 seem to have had little effect on the bond market. Although a statistically significant drop in the 1-year yield is observed around the April 6 announcement, that response is not in the direction predicted by the alternative, so it would not be significant for a one-sided test. The Wald statistic for the February 9 announcement is 5.0, with a $p$ value of 55 percent, and the Wald statistic for April 6 is 10.9, with a $p$ value of 9.2 percent.

Given the size and statistical significance of these responses to individual announcements, it is natural to investigate the size and significance of the effect of Operation Twist as a whole, which this paper does in two ways. The first is to look at the cumulative effect of the first four announcements in the sample, each of which represented an increase in Treasury or Federal Reserve commitment to Operation Twist. Taken together, these first four announcements provide a reasonable estimate of the initial effects of Operation Twist on the yield curve: not only is each of these announcements in the same direction, but they all occur within a period of 3 weeks during which essentially no other news regarding Operation Twist was released. As a result, one can have a high degree of confidence that these first four announcements capture essentially all of the information regarding Operation Twist that was released within the first 3 weeks of the program. One can interpret this cumulative effect as the initial effect of Operation Twist or what the total effect could have been with no future policy reversals or mixed signals.

The second way of investigating the overall effect of Operation Twist is by looking at the cumulative effect of all six of the announcements in the sample. Here, the interpretation is less clear-cut: For example, the 
fifth announcement, on March 15, reversed some of the initial effects of the program. In addition, more time elapsed between the fourth and fifth, and fifth and sixth announcements, and after the sixth announcement, than between earlier announcements; as a result, there is more time for incremental information about Operation Twist to come to light, such as the weekly breakdown of Treasury holdings released by the Federal Reserve, periodic issuance and refunding announcements by the Treasury, and the actual quantities of securities purchased and issued by the Federal Reserve and the Treasury. Nevertheless, summing up the effects of the six announcements in the sample gives an estimate of the total effects of Operation Twist, inclusive of the effects of policy reversals.

These cumulative changes are reported in the third panel of table 3 . The statistical significance of the cumulative changes is assessed by comparing them with the unconditional standard deviations of yields over a correspondingly sized 6- or 8-day window, reported in the bottom panel..$^{40}$ As the table shows, the cumulative change in yields after the first four announcements is highly statistically significant and in the direction predicted by the alternative. The Wald statistic for the joint yield curve response is 61.3 , with a $p$ value of less than $10^{-10}$. The cumulative effect, however, is moderate, amounting to no more than about $15 \mathrm{bp}$ even at the longest and the shortest maturities.

The cumulative effect of all six announcements is somewhat smaller and is statistically significant only at the longest and the shortest maturities (10 years, 30 years, and 3 months), although the $t$ statistics for the long maturities remain close to 3 , and the 3 -month response is significant at the 5 percent level in the direction of the alternative. The Wald statistic for the joint response is 30.2 , with a $p$ value of less than $10^{-4}$. The total effect on the longest and the shortest maturities appears to have been about 12 to $13 \mathrm{bp}$.

Thus, even though this analysis finds a highly statistically significant cumulative effect of Operation Twist on longer-term Treasury yields, one could argue that, at 15 basis points, the effect is not very important economically. Indeed, Modigliani and Sutch (1966, p. 196) argued, "Any effects, direct or indirect, of Operation Twist in narrowing the spread which further study might establish, are most unlikely to exceed some ten to twenty base

40. These 6-day and 8-day standard deviations are computed as $\sqrt{2 \mathrm{sd}_{1}^{2}+2 \mathrm{sd}_{2}^{2}}$ and $\sqrt{4 \mathrm{sd}_{1}^{2}+2 \mathrm{sd}_{2}^{2}}$, respectively, where $\mathrm{sd}_{1}$ and $\mathrm{sd}_{2}$ denote the standard deviations of 1 - and 2-day changes. 
points - a reduction that can be considered moderate at best." However, it should be noted that a 15-bp decline in the 10-year Treasury yield would be a typical response to a 100-bp surprise cut in the federal funds rate target (Gürkaynak, Sack, and Swanson, 2005). Such a change would usually be regarded as a nonnegligible easing of financial market conditions. ${ }^{41}$

Whether a reduction of $15 \mathrm{bp}$ in long-term interest rates is economically significant or not may ultimately lie in the eye of the beholder. Nevertheless, it is reassuring that the effects in table 3 are consistent with Modigliani and Sutch's findings. As discussed above, the standard error of those authors' quarterly regression specification is over $9 \mathrm{bp}$, too large for the effects in table 3 to show up with any statistical significance in their analysis.

\section{Comparisons with Other Studies}

Although the consistency of our results with Modigliani and Sutch's $(1966,1967)$ extensive analysis is reassuring, the literature contains a number of more recent studies of the effects of changes in the supply of Treasury securities and the announcement effects of such changes. For the purpose of comparability across studies, each estimate discussed in what follows is normalized in terms of its predicted effect for QE2, that is, the effect that an announcement of a $\$ 600$ billion reduction in the supply of longer-term Treasury securities would have on longer-term Treasury yields. ${ }^{42}$ As discussed in section I, Operation Twist and QE2 can be seen as roughly similar in size, so that the effect predicted by the present paper for QE2 would be about 15 bp. ${ }^{43}$

Gagnon and others (2011) study the Federal Reserve's purchases of longer-term Treasury and mortgage-backed securities between 2008 and mid-2009—what has been referred to as QE1. Using both high-frequency

41. However, a 100-bp cut in the federal funds rate would also typically imply large declines in short-term rates, whereas the effect of Operation Twist on short- and medium-term rates was zero or even positive. Thus, the effect of Operation Twist on the macroeconomy should not be thought of as equivalent to a 100-bp cut in the funds rate.

42. Some of the studies focus only on changes in the supply of Treasury securities, whereas others (particularly the event studies) implicitly include signaling effects as well as direct effects of changes in Treasury supply. In each case I simply scale the study's coefficient estimate to correspond to a change in Treasury supply of $\$ 600$ billion. If the study in question excluded signaling effects, then the scaled-up estimate reported below also excludes signaling effects.

43. Implicit in this comparison is an assumption that any signaling effects of QE2 regarding fiscal and monetary policy are also roughly similar in size to any signals that markets inferred from Operation Twist. 
event-study methods and a lower-frequency (monthly) time-series analysis, Gagnon and his coauthors estimate that QE1 had an effect on the 10-year Treasury yield of about 91 bp using their event-study methodology, and $52 \mathrm{bp}$ according to their monthly time-series regressions. Since the $\$ 1.7$ trillion QE1 program was roughly three times the size of QE2, this would imply an effect of QE2 on the 10-year Treasury yield of about 17 to $30 \mathrm{bp}$. The estimates in this paper are consistent with the very bottom of this range. To the extent that this represents a discrepancy, it may be due to the fact that QE1 took place during a period of severe disruption and very low liquidity in financial markets (see, for example, Gürkaynak and Wright 2011), an environment in which those markets may have been more segmented and supply effects may have been correspondingly more potent. ${ }^{44}$

D'Amico and King (2010) estimate the effects of Federal Reserve purchases of Treasury securities during QE1 using a panel dataset containing the quantity, maturity, date of purchase, and CUSIP of each Treasury security purchased by the Federal Reserve throughout the program. Using differences in the cross section of Treasury bond prices to estimate the effect of the Federal Reserve's purchases on Treasury yields, they estimate that, overall, the effect of the $\$ 300$ billion Treasury component of QE1 on the 10-year Treasury yield was about $50 \mathrm{bp}$. Scaling this up to the size of QE2 implies an effect on the 10-year Treasury yield of about $100 \mathrm{bp}$, far larger than the effect estimated in this paper. Like those of Gagnon and others (2011), D'Amico and King's (2010) larger estimates may be due to greater market segmentation during the QE1 period, which would have made it easier for the Federal Reserve to move yields in any given market segment. Nevertheless, their estimates are substantially larger than the Federal Reserve's apparent experience during Operation Twist.

James Hamilton and Jing Wu (forthcoming) relate Treasury supply effects to an affine term structure model using a preferred-habitat framework developed by Dimitri Vayanos and Jean-Luc Vila (2009). Hamilton and $\mathrm{Wu}$ estimate that $\$ 400$ billion of Treasury purchases by the Federal Reserve, focused on 21/2- to 10-year maturities as in QE2, would decrease the 10-year Treasury yield by about $11 \mathrm{bp}$. Scaled up to the size of QE2 and Operation Twist, this would imply an effect of about $17 \mathrm{bp}$, consistent with the present paper.

44. It is also possible that financial markets interpreted QE1 as a signal that the Federal Reserve would do what was necessary to prevent a complete financial collapse; in that case the signaling effects of QE1 would have been greater than those of QE2 or Operation Twist. However, the sign of this effect is not clear-for example, such a signal could have increased Treasury yields by reducing the demand for default-free assets. 
Robin Greenwood and Vayanos (2008) regress the monthly Treasury yield spread - the difference between long-term and short-term Treasury yields - on measures of the long-term (10+ years to maturity) share of Treasury debt outstanding. They estimate that a 1 percent increase in the long-term share of Treasury debt increases the 20-year Treasury yield by $7.7 \mathrm{bp}$. Scaled up to the size of Operation Twist and QE2, this would seem to imply an effect of those programs of about 36 and $54 \mathrm{bp}$, respectively (using the numbers in table 1). However, most of the Federal Reserve's purchases of Treasury securities during Operation Twist and QE2 were concentrated at intermediate maturities (less than 10 years), and only a small fraction (about one-fourth) took place at maturities of 10 years or more. When this difference is taken into account, Greenwood and Vayanos's estimates would imply an effect of those programs of roughly 9 to $14 \mathrm{bp}$, consistent with the findings of this paper.

Arvind Krishnamurthy and Annette Vissing-Jorgensen (2007) measure the effect of total Treasury supply on the overall level of Treasury yields relative to yields on triple-A-rated corporate bonds. They estimate that an increase in the total quantity of Treasuries outstanding equal to 1 percent of GDP raises Treasury yields overall by about 1.5 to $4.25 \mathrm{bp}$. This estimated effect is of the same order of magnitude as in the present paper (QE2 is about 4 percent of GDP), but the two estimates are nevertheless not directly comparable, because Krishnamurthy and Vissing-Jorgensen's analysis focuses on the total quantity of Treasury debt outstanding, whereas Operation Twist and QE2 involved no change in total Treasury debt, only a change in the relative supply of shorter- versus longer-maturity Treasury securities.

Warnock and Warnock (2009) estimate the effect of foreign official purchases of U.S. Treasury securities on Treasury yields. The idea is that purchases of Treasury securities by, for example, the Bank of China or the Bank of Japan are made primarily for exogenous reasons relating to the domestic economy or exchange rate interventions and thus represent exogenous changes in the net supply of Treasuries to the private sector. They estimate that a decrease in the supply of Treasury securities of about 1 percent of U.S. GDP reduces the 10-year Treasury yield by about $19 \mathrm{bp}$. Scaling this up to the size of Operation Twist and QE2 would imply reductions in longer-term Treasury yields of roughly 32 and $76 \mathrm{bp}$, respectively, substantially larger than the effect estimated by Krishnamurthy and VissingJorgensen (2010). Again, Warnock and Warnock's estimates are not directly comparable to those of the present paper, since Operation Twist and QE2 changed only the composition, not the total quantity, of Treasury debt outstanding. 
It is reassuring that several of the studies cited above, using completely different methods and a variety of samples, arrive at estimates of the effects of QE2 that are in line with those of this paper. A potential concern with the event-study methodology in general is that it restricts attention to only those newsworthy announcements that can be pinpointed to an exact date. If much of the news regarding Operation Twist was released incrementally, in between and after the six major announcements in table 2, then estimates of the cumulative effect of the six discrete announcements might miss much of the true cumulative effect of Operation Twist. The studies by Hamilton and $\mathrm{Wu}$ (forthcoming) and Greenwood and Vayanos (2008) do not suffer from this criticism, and so their findings provide some evidence that the six major announcements analyzed here may indeed have captured a large majority of the information and effects of the program.

\section{The Response of Agency and Corporate Yields to Operation Twist}

The previous section showed that Operation Twist had highly statistically significant but economically moderate effects on Treasury yields. The results in Krishnamurthy and Vissing-Jorgensen $(2010,2011)$ suggest that these effects may not pass through completely to yields on debt instruments other than Treasuries, so this section investigates to what extent the effects of Operation Twist spilled over to interest rates more generally.

\section{V.A. Agency and Corporate Yield Results}

Table 4 reports the behavior of short- and long-term agency and corporate borrowing rates around the six Operation Twist announcements identified above.

The first four columns of table 4 report yields on government-sponsored agency securities around each of the same announcements as in tables 2 and $3 .{ }^{45}$ The next three columns report commercial paper yields, which are short-term borrowing rates available to large corporations. The next two columns report interest rates on long-term corporate borrowing as measured by Moody's corporate bond indexes. The final two columns report the corresponding 1- and 10-year Treasury yields as benchmarks for comparison.

45. The Federal Land Bank system was a large issuer of government agency bonds in the first half of the twentieth century, with more securities outstanding in 1961 than even Fannie Mae. Together, Fannie Mae and Federal Land Bank notes dominated the government agency listings in the Wall Street Journal and the New York Times. 
The event windows in the top panel of table 4 are 1 day longer than those in table 3, for two reasons. ${ }^{46}$ First, there is some evidence that the (less liquid) agency and corporate securities considered here may respond with a longer lag than do the Treasury securities in table 3 . The strongest evidence appears after the Federal Reserve's announcement late on February 20, for which Treasury yields seem to respond on February 21 and not on February 23 (the next trading day after Washington's Birthday), whereas agency and commercial paper yields show little response on February 21 but a great deal of movement on February 23. The same effect is visible for agency yields around other announcement dates as well. ${ }^{47}$

The second reason to consider longer event windows in table 4 is pragmatic: because the response of corporate yields to Operation Twist announcements as found below is generally small, those markets are given the benefit of the doubt and allowed more time to respond to each announcement. The longer event windows considered in table 4 increase the size and statistical significance of the agency and corporate yield responses to Operation Twist; using the shorter event windows of table 3 would lead to estimates of even smaller and less statistically significant effects for these yields. (The response of Treasury yields over these longer event windows is very similar to that over the shorter windows, as can be seen by comparing the last columns of table 4 with the corresponding columns in table 3.)

The second panel of table 4 reports the changes in agency, commercial paper, and corporate bond yields across the event window for each announcement. The statistical significance of each response is measured relative to the unconditional standard deviation of the corresponding yield over similarly sized windows in 1962 , reported in the bottom panel. ${ }^{48}$

Of the six announcements, the one that stands out the most in this analysis is the Federal Reserve's explicit endorsement of Operation Twist on

46. A 1-day event window is again used for the first announcement because a longer window would overlap with the second announcement and lead to double counting.

47. Krishnamurthy and Vissing-Jorgensen (2011) also find that more than 1 day is needed for the effects of announcements during QE1 and QE2 to become evident in less liquid securities markets such as those for agency and corporate bonds.

48. For commercial paper, Moody's bond indexes, and Treasuries, 1-, 2-, and 3-day standard deviations were computed directly from daily data. The 9- and 13-day standard deviations were then computed as $\sqrt{\mathrm{sd}_{1}^{2}+\mathrm{sd}_{2}^{2}+2 \mathrm{sd}_{3}^{2}}$ and $\sqrt{\mathrm{sd}_{1}^{2}+3 \mathrm{sd}_{2}^{2}+2 \mathrm{sd}_{3}^{2}}$, respectively. For agencies, weekly data on yields in late 1961 and 1962 were collected from the Wall Street Journal, the 5-day standard deviation $\left(\mathrm{sd}_{5}\right)$ was computed directly from the weekly data, and then the $n$-day standard deviations $\operatorname{sd}_{n}$ were set as $\operatorname{sd}_{n}=\sqrt{n \mathrm{sd}_{5}^{2} / 5}$. 


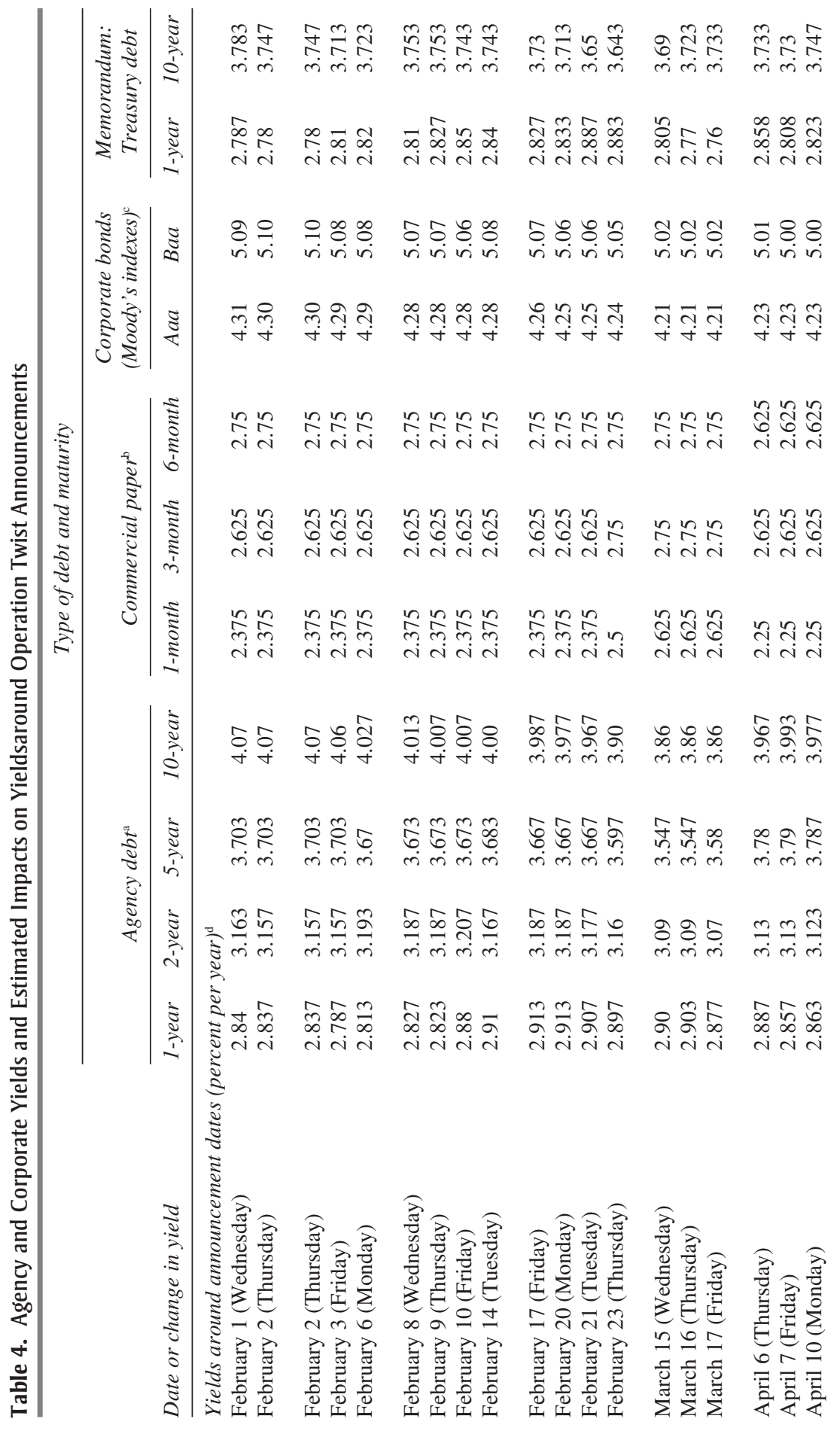




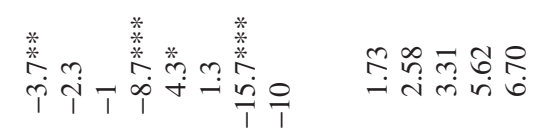

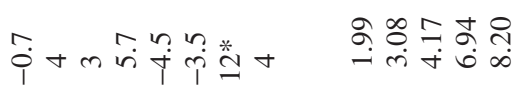

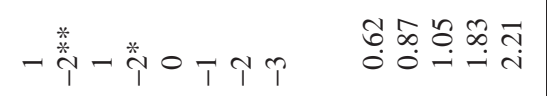

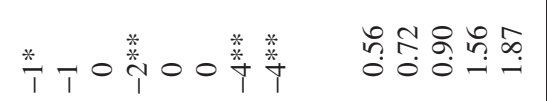

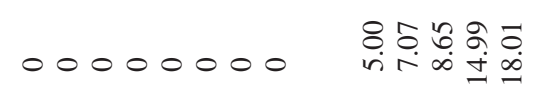

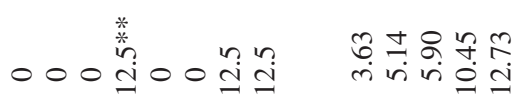

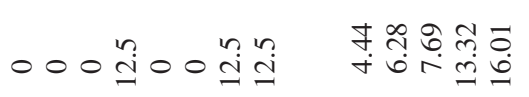

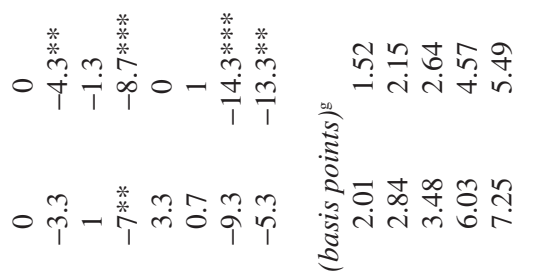

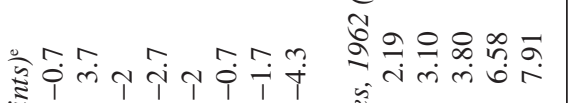

$$
\begin{aligned}
& \text { : }
\end{aligned}
$$

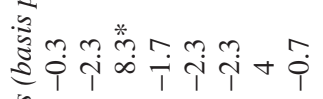

$$
\begin{aligned}
& \text { ఏ }
\end{aligned}
$$

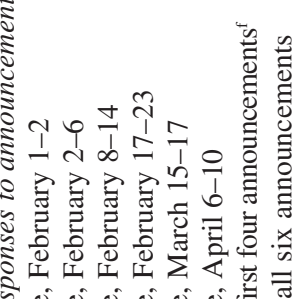

$$
\begin{aligned}
& \text { 政过 }
\end{aligned}
$$

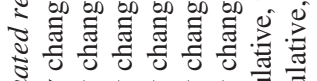

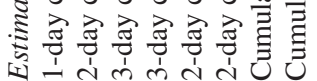

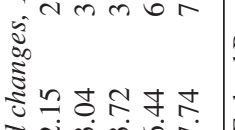

$$
\begin{aligned}
& \text { 要 } \\
& \text { ऽ } \\
& \frac{\sqrt{2}}{3} \cdot \frac{1}{3}
\end{aligned}
$$

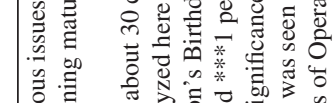

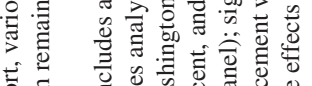

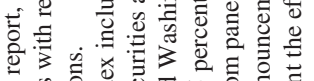

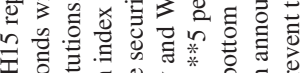

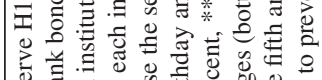

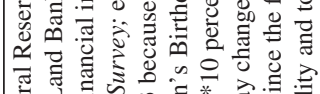

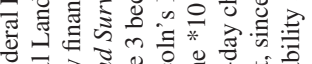

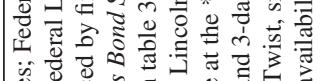

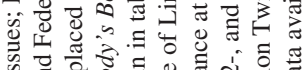

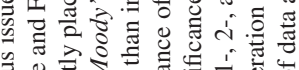

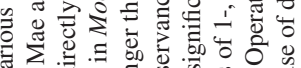

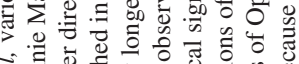

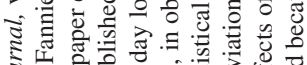

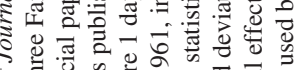

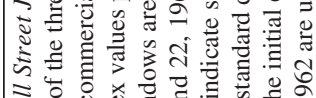

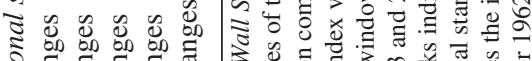

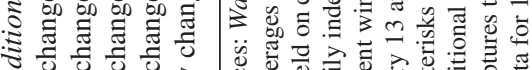


February 20. Long-term agency, commercial paper, and corporate bond yields all responded substantially, and in most cases statistically significantly, to the announcement. The Treasury's refunding announcement on February 2 is also noteworthy, with moderately large and significant responses of 10-year agency bonds and Moody's Baa index (although part of the response may reflect a carryover from President Kennedy's announcement earlier that same day). The March 15 announcement is also interesting in that the response of the 5-year agency yield is moderate ( $3.3 \mathrm{bp}$ ) and in the same direction as the 5-year Treasury yield, although not statistically significant. (Recall that the Treasury's refunding announcement had an outsized effect on yields at precisely the 5-year maturity, at which the new issuance was concentrated.) The Moody's corporate bond indexes, which refer to bonds with 10 to 30 years remaining to maturity and thus differ substantially from the new issues announced by the Treasury, show no response to the March 15 announcement.

The third panel of table 4 estimates the total effect of Operation Twist on agency and corporate yields by summing over their responses to the first four and all six announcements, as was done in the third panel of table 3. The cumulative response of 10-year agency yields is highly statistically significant and moderate, about 13 to $14 \mathrm{bp}$, similar to the roughly 15-bp cumulative response of long-term Treasuries. This suggests that Operation Twist had substantial spillovers from Treasury to agency yields at the longest maturities. However, the cumulative response of 5-year agency yields to either the first four or all six announcements is not statistically significant and, at 5 to $9 \mathrm{bp}$, is more muted than that of the 5-year Treasury yield in table 3. There is also little evidence of pass-through of Operation Twist to 1-year agency yields (and the cumulative responses of 2-year agencies and Treasuries are both insignificant).

The cumulative response of commercial paper yields in table 4 is likewise not significant, and those yields do not respond to any of the six announcements in the table except that of February 20. To some extent this may reflect the fact that the commercial paper yields in the sample were expressed only in increments of $1 / 8$ percentage point, which is such a coarse resolution that any announcement effects could be difficult to observe. The cumulative effect of Operation Twist on 1- and 3-month commercial paper yields is of roughly the same magnitude as the effect on short-term Treasury yieldsabout $12 \mathrm{bp}$ - but is not statistically significant, because of the much larger standard deviation of changes in commercial paper yields.

In contrast to the data on commercial paper yields during this period, Moody's corporate bond indexes are calculated to the nearest basis point 
and have small standard deviations, and the underlying bonds have 10 to 30 years remaining to maturity, precisely matching the region of the Treasury yield curve that responded the most to Operation Twist. Nevertheless, the response of corporate bonds to Operation Twist appears to have been quite modest, no more than 1 or $2 \mathrm{bp}$ in response to any single announcement, and no more than 2 to $4 \mathrm{bp}$ cumulatively (although many of these responses are statistically significant). The 4-bp cumulative response of Aaa-rated corporate bonds to Operation Twist is both larger and more significant than the response of the Baa-rated bonds, consistent with the former being closer substitutes for long-term Treasuries. But even the 4-bp fall in Aaa bond yields is far less than the 13- to 14-bp drop in agency yields.

\section{V.B. Discussion of Agency and Corporate Yield Responses}

The observation that corporate bonds responded less to Operation Twist than did agencies and Treasuries is in line with a similar finding by Krishnamurthy and Vissing-Jorgensen (2011) for QE2 and has two main interpretations. First, it could be that the Moody's Aaa and Baa corporate bond indexes are simply very slow to respond to news and require even more than 2 days to respond to each of the Operation Twist announcements. For example, if many of the individual bonds in the Moody's index were illiquid, and the bond indexes themselves were based on transaction prices, it could have taken the indexes several days to fully respond to news, the precise delay depending on the liquidity of the underlying bonds. Alternatively, one could argue that the purchases of long-term Treasury securities in Operation Twist primarily affected long-term Treasury yields and spilled over to other markets only to the extent that the securities in those markets are substitutes for long-term Treasuries. If corporate bonds are not very good substitutes for long-term Treasuries, the spillovers from Operation Twist to even the highest-quality corporate bond markets could have been quite small.

There are a few reasons to be suspicious of an explanation that relies entirely on illiquidity. First, bond yield quotations in the newspapers and in Moody's Bond Survey are not transaction prices but rather are based on the bid and offer prices of dealers who make a market for each type of bond (for example, the quoted yield is often the midpoint between bid and offer). Thus, even if no transactions for a particular bond take place, one should still see the quoted yield respond to news as the dealers' bid and offer prices respond. One would think that 2 days would be a sufficiently long time for dealers to adjust their stated bids and offers.

Second, if the Moody's indexes were slow to respond to news, one would expect daily changes in those bond indexes to be positively serially 
correlated. In fact, the serial correlations of daily changes in Moody's Aaa and Baa indexes in 1962 are low, -0.09 and -0.06 , respectively, and are not statistically significant, which is inconsistent with the view that those indexes systematically responded sluggishly to news. ${ }^{49}$

Third, Krishnamurthy and Vissing-Jorgensen (2011) observe the same phenomenon for QE2 that this paper finds for Operation Twist. To the extent that U.S. corporate bond markets have become deeper and more liquid over time, one would expect Moody's corporate bond indexes to behave more like agency and Treasury yields during QE2. In fact, Gagnon and others (2011) find that corporate bonds did respond by an amount closer to agencies and Treasuries during QE1..$^{50}$ Thus, the fact that Krishnamurthy and VissingJorgensen's estimates for QE2 agree with those in the present paper suggests that low corporate bond liquidity is not by itself a sufficient explanation.

In contrast, the hypothesis that Operation Twist (and QE2) had smaller effects on securities that were less substitutable for long-term Treasuries can potentially explain all of the results both in the present paper and in Krishnamurthy and Vissing-Jorgensen's. Long-term Treasury yields responded the most to the program. Yields on long-term agency debt, which is very similar to long-term Treasury debt in many respects, also seem to have responded substantially. Aaa corporate bonds responded less, and Baa bonds even less than Aaa bonds.

Under this interpretation, QE1 could have had a larger impact on corporate yields than did QE2 or Operation Twist, for two main reasons. First, almost $\$ 1.3$ trillion of the assets purchased in QE1 were mortgage-backed securities rather than Treasuries; since the market for these securities is more similar to private sector borrowing markets, those markets may have experienced larger effects during QE1 simply because the securities traded in them were closer substitutes for the securities actually being purchased. Second, QE1 took place during a time of severe financial and economic stress, and the program may have been perceived by markets as substantially diminishing the probability of a second Great Depression, which could have been associated with widespread defaults by Baa- and even Aaa-rated

49. The serial correlation of Treasury yield changes was also about zero in 1962 . The lower standard deviation of Moody's indexes relative to Treasuries does not necessarily imply that the yields diverge over time. In 1962 both Treasury yields and Moody's indexes declined by about $20 \mathrm{bp}$, so the average daily yield change was about the same, but the volatility of the Moody's indexes around that average was lower.

50. Gagnon and others (2011) find a cumulative response of 10-year Treasuries of $91 \mathrm{bp}$ to their five baseline QE1 events; 10-year agency yields fell $156 \mathrm{bp}$, and Moody's corporate Baa index fell $67 \mathrm{bp}$. 
corporations. If the markets viewed QE1 as markedly reducing the probability of investment-grade corporate bond defaults, then one would expect to see corporate bond yields fall more sharply than otherwise.

This is not to say that low liquidity is necessarily unrelated to the small estimated response of corporate bond yields to Operation Twist. The unconditional standard deviation of those bond indexes in 1962 was surprisingly small, and their standard deviation has steadily increased relative to that of the 10-year Treasury yield over time..$^{51}$ But the evidence presented above suggests that some features of the data are not well explained by liquidity alone. Meanwhile, the fact that Baa- and even Aaa-rated corporate bonds are imperfect substitutes for Treasuries is consistent with all of the observations in this paper.

\section{Conclusions}

For more than forty years, the conventional wisdom regarding Operation Twist has been driven by the results of low-frequency time-series studies, particularly Modigliani and Sutch (1966, 1967). However, these lower-frequency methods have inherent problems, such as unobserved expectational variables, large standard errors, and in particular the possibility of endogeneity if the Federal Reserve increased its purchases of longerterm Treasury securities in response to upward pressure on longer-term interest rates.

The present paper has reexamined Operation Twist using a modern, high-frequency event-study approach, which avoids the problems with lower-frequency methods just mentioned. In contrast to Modigliani and Sutch, this paper finds that Operation Twist had a highly statistically significant impact on longer-term Treasury yields. However, consistent with those authors' results, the paper also finds that the effect was moderate in size, amounting to about 15 basis points. This estimate is also consistent with the lower end of the range of estimates of Treasury supply effects in the literature.

Operation Twist appears to have had diminishing effects as one moves from long-term Treasuries toward private sector credit instruments. To some extent this may reflect a slower response of non-Treasury securities to

51. In 1962 the daily standard deviation of the Aaa and Baa indexes was about one-third the daily standard deviation of the 10-year Treasury yield (table 4). In 1986, the first year for which Moody's daily data are available electronically, the relative standard deviation was 0.5 . By the late 1990 s it had risen to 0.8 , and by the late 2000 s it was up to 1.0 . 
Operation Twist announcements, perhaps in part because of lower liquidity, but low liquidity alone seems insufficient to explain all the features of the data. Part of the difference in responses may simply reflect the fact that purchases of Treasuries have the greatest effect on the Treasury market itself and affect other markets only to the extent that the securities in those markets are substitutes for Treasuries.

Because Operation Twist and QE2 are similar in many important respects, it seems reasonable to expect the effects of QE2 to be similar to those of Operation Twist, reducing longer-term Treasury yields by about $15 \mathrm{bp}$ and Aaa- and Baa-rated corporate bonds by only a few basis points. Thus, if the goal of quantitative programs such as QE2 is to reduce interest rates for private sector borrowers, purchases of Treasury securities may not be the most effective means of attaining that goal. Instead, purchases of mortgage-backed securities, or other securities more similar to private sector credit instruments, may reduce private sector borrowing rates more substantially and ultimately have a greater effect on macroeconomic variables.

Finally, the benefits of these programs in terms of lower interest rates must be weighed against their costs when assessing their overall desirability. Although this paper has not attempted to estimate the costs of Operation Twist or QE2, those costs are as important as the benefits for policy analysis, and thus future work on the nature and size of such costs would be welcome.

ACKNOWLEDG M ENTS I thank Robin Greenwood, Arvind Krishnamurthy, Edward Nelson, seminar participants at the Federal Reserve Bank of San Francisco, Stanford University, and the Brookings Papers conference, and especially the discussants, Lucrezia Reichlin and Jonathan Wright, and the editors, for very helpful comments and suggestions. I thank Arvind Krishnamurthy for pointing me to the historical data on Moody's corporate bond indexes. I thank Kan Kin and especially Titan Alon for valuable archival work and research assistance. The views expressed in this paper, and all errors and omissions, should be regarded as those solely of the author and are not necessarily those of the individuals listed above, the management of the Federal Reserve Bank of San Francisco, or any other individual in the Federal Reserve System.

The author was employed as a senior research advisor on the staff of the Federal Reserve Bank of San Francisco while this paper was written and while QE2 was being conducted. 


\section{References}

Bernanke, Ben S. 2010. "The Economic Outlook and Monetary Policy." Speech at the Federal Reserve Bank of Kansas City Economic Symposium, Jackson Hole, Wyoming, August 27, 2010.

Christiano, Lawrence J., Martin Eichenbaum, and Charles L. Evans. 1999. "Monetary Policy Shocks: What Have We Learned and to What End?" In Handbook of Macroeconomics, Vol. 1A, edited by John B. Taylor and Michael Woodford. Amsterdam: Elsevier.

D'Amico, Stefania, and Thomas B. King. 2010. "Flow and Stock Effects of LargeScale Treasury Purchases." Finance and Economics Discussion Series 2010-52. Washington: Federal Reserve Board.

Faust, Jon, Eric T. Swanson, and Jonathan H. Wright. 2004. "Identifying VARs Based on High-Frequency Futures Data." Journal of Monetary Economics 51: 1107-31.

Fleming, Michael J., and Eli M. Remolona. 1999. "Price Formation and Liquidity in the U.S. Treasury Market: The Response to Public Information." Journal of Finance 54, no. 5: 1901-15.

Friedman, Milton, and Anna Jacobson Schwartz. 1963. A Monetary History of the United States, 1867-1960. Princeton University Press.

Gagnon, Joseph, Matthew Raskin, Julie Remache, and Brian Sack. 2011. "The Financial Market Effects of the Federal Reserve's Large-Scale Asset Purchases." International Journal of Central Banking 7, no. 1: 3-43.

Greenwood, Robin, and Dimitri Vayanos. 2008. "Bond Supply and Excess Bond Returns." Working Paper no. 13806. Cambridge, Mass.: National Bureau of Economic Research.

Gürkaynak, Refet S., and Jonathan H. Wright. Forthcoming. "Macroeconomics and the Term Structure." Journal of Economic Literature.

Gürkaynak, Refet, Brian Sack, and Eric Swanson. 2005. "Do Actions Speak Louder Than Words? The Response of Asset Prices to Monetary Policy Actions and Statements." International Journal of Central Banking 1: 55-93.

Hamilton, James D., and Jing Cynthia Wu. Forthcoming. "The Effectiveness of Alternative Monetary Policy Tools in a Zero Lower Bound Environment." Journal of Money, Credit, and Banking.

Jones, Charles M., Owen Lamont, and Robin L. Lumsdaine. 1998. "Macroeconomic News and Bond Market Volatility." Journal of Financial Economics 47, no. 3: 315-37.

Krishnamurthy, Arvind, and Annette Vissing-Jorgensen. 2007. "The Demand for Treasury Debt.” Working Paper no. 12881. Cambridge, Mass.: National Bureau of Economic Research.

—. 2011. "The Effects of Quantitative Easing on Interest Rates." Northwestern University.

Meulendyke, Ann-Marie. 1998. U.S. Monetary Policy and Financial Markets. Federal Reserve Bank of New York. 
Modigliani, Franco, and Richard Sutch. 1966. "Innovations in Interest Rate Policy." American Economic Review 56, no. 1/2: 178-97.

1967. "Debt Management and the Term Structure of Interest Rates: An Empirical Analysis of Recent Experience.” Journal of Political Economy 75, no. 4, part 2: 569-89.

Scott, Ira O., Jr. 1965. Government Securities Market. McGraw-Hill.

Vayanos, Dimitri, and Jean-Luc Vila. 2009. "A Preferred-Habitat Model of the Term Structure of Interest Rates.” Working Paper no. 15487. Cambridge, Mass.: National Bureau of Economic Research.

Warnock, Francis E., and Veronica Cacdac Warnock. 2009. "International Capital Flows and U.S. Interest Rates." Journal of International Money and Finance 28: 903-19.

Woolley, John T., and Gerhard Peters. 2010. The American Presidency Project. University of California, Santa Barbara. www.presidency.ucsb.edu/ws/?pid=8111. 


\section{Comments and Discussion}

\section{COMMENT BY}

LUCREZIA REICHLIN This paper by Eric Swanson is an interesting one. The empirical strategy is creative and consists in using a historical example to shed light on a current policy problem and in applying modern econometrics to reevaluate established empirical evidence from papers written more than forty years ago.

The case study is Operation Twist, an early experiment in quantitative easing. The idea of the paper is to measure the size and statistical significance of the effect of that operation by means of an event study, and use those results to evaluate the potential effects of the Federal Reserve's recent quantitative easing operation, known as QE2.

I will start by assessing whether Operation Twist is an appropriate case study to be used as an input for assessing the effects of QE2 on the term spread. Then I will discuss the event-study methodology as a tool for studying the effects of Operation Twist. Finally, I will report some results from an analysis using euro-area data on the effect of an alternative policy conducted by the European Central Bank (ECB) as a response to the recent financial crisis. This policy, rather than trying to influence the long-term interest rate by buying long-term government bonds, fixed the interest rate at 1 -year maturity in repo operations with financial institutions. An interesting question is which of the two policies has a chance to be more successful in influencing market interest rates, such as those on loans to corporations. This, of course, leads to the question of what the transmission mechanism of these nonstandard monetary policy interventions might be.

WHY IS OPERATION TWIST AN INTERESTING CASE STUDY FOR UNDERSTANDING QE2? Like QE2, Operation Twist sought to affect long-term yields on government bonds while keeping the policy interest rate (in the United States, the federal funds rate) constant. This motivation and the communications associated 
with it are different from those in the previous quantitative easing (QE1). In that operation the goals, as communicated at the time (Bernanke 2009), were to ease credit where needed and to narrow key spreads through a change in the composition of the central bank's assets. Whereas the motivation behind QE1 was similar to that of credit policies implemented at the ECB in the same period, QE2 is more easily compared with recent nonstandard monetary policies at the Bank of England. In this sense the experience of Operation Twist is more relevant for QE2 than for QE1.

There are other reasons why Operation Twist is relevant for QE2. First, as Swanson emphasizes, the two operations were similar in size. According to his calculations, Operation Twist was approximately two-thirds the size of QE2 when measured as a percentage of U.S. Treasury debt, and about half its size when measured as a percentage of GDP. Moreover, both operations were conducted at times when financial markets were not exceptionally dysfunctional; at the time of QE1, in contrast, markets were illiquid and counterparty risk was widespread. This is an important observation because in periods of financial stress, policies based on the manipulation of quantities are likely to have larger effects. In fact, according to standard finance theory, these policies should be expected to have no effect at all when markets function perfectly.

But there are also many differences between the two episodes which are likely to have affected expectations in different ways. The first is the phase of the business cycle: Operation Twist started in February 1961, a month in which the economy reached a trough, according to the standard chronology, whereas QE2 was announced 1 year after the beginning of the recovery from the 2007-09 recession and in a period of greater uncertainty about the outlook. This is relevant because perceptions of the state of the economy are likely to influence the volatility of long-term rates, and in comparing the two policy periods it is important to control for these differences.

Second, the funding of the programs was different. Operation Twist was essentially a swap of short-term for long-term bonds implemented by the Federal Reserve and the Treasury in cooperation, whereas QE2 is funded by reserves and conducted by the Federal Reserve alone. These differences are likely to have affected inflation expectations differently and therefore to have had different effects on long-term rates.

The same is true for communication. QE2 has been described as a more open-ended policy, not only interpreted but also communicated by some Federal Reserve governors as a commitment to a future low policy rate. More generally, official communications about QE2 have been confusing. 
Figure 1. The Policy Interest Rate, Long-Term Rates, and Inflation in Operation Twist and QE2
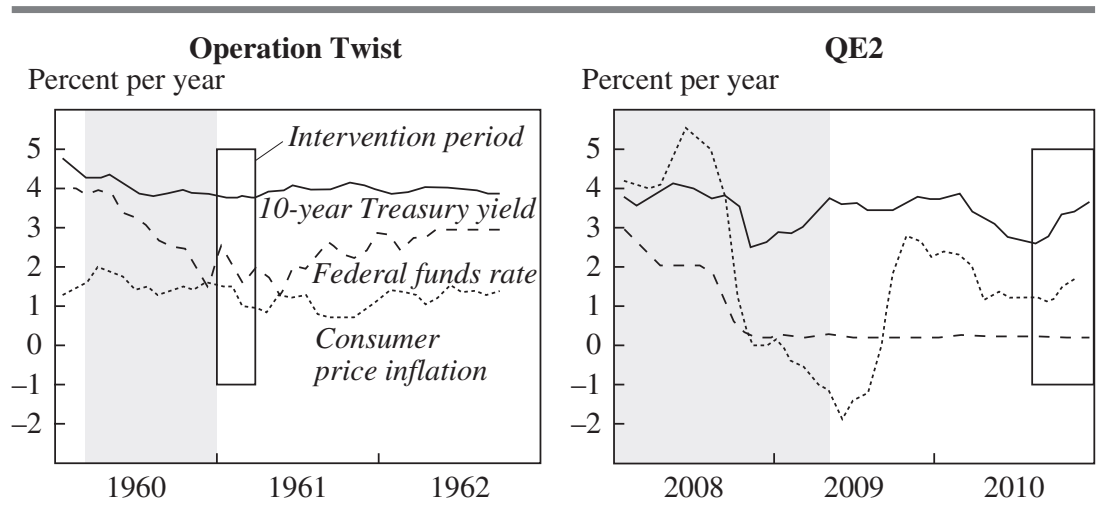

Source: Federal Reserve Bank of St. Louis. a. Shading indicates recessions.

Federal Reserve Chairman Ben Bernanke, in his speech at the 2010 Jackson Hole conference, said, "The channels through which the Fed's purchases affect longer-term interest rates and financial conditions more generally have been subject to debate. I see the evidence as most favorable to the view that such purchases work primarily through the so-called portfolio balance channel" (Bernanke 2010, p. 9). But this channel may work only under very special assumptions (see Woodford 2011 for a critical discussion), and it is not clear how its operation is understood by the market. Another channel, associated in particular with purchases of government bonds financed by reserves, is the effect on inflation expectations. QE2 may in fact have worked through this effect, and indeed some speeches by Federal Reserve governors (for example, Bullard 2010) seem to suggest that this is the mechanism they had in mind.

Although event studies attempt to control for the state of the economy by focusing on a narrow window, the level of market uncertainty, the expected changes in the policy rate related to expected inflation and business cycle conditions, and the way the policy has been communicated are all likely to affect the market's reactions to announcements even when measured within such a window. To demonstrate the relevance of these considerations, my figure 1 depicts the 10-year Treasury rate, consumer price inflation, and the policy rate around each of the two policy episodes. The difference in the dynamics of these variables across these episodes is striking. Consider Operation Twist first: after an immediate increase, the policy rate decreased quite sharply, while the 10-year yield was flat and inflation decreased. In 
contrast, during QE2, both the 10-year yield and inflation increased, while the policy rate remained flat at zero. Clearly the general economic situation was very different in the two policy episodes.

MODIGLIANI AND SUTCH 1967 VERSUS SWANSON 2011. In their classic contribution, Franco Modigliani and Richard Sutch (1967) undertook a counterfactual exercise: after the inception of Operation Twist, was the spread between long-term and short-term rates in the government bond market different from what one might have expected from the pre-Operation Twist relationship? Their finding was that the discrepancy between the observed spread and what would have been expected given the historical correlation between the spread and short-term rates was small: about 13 basis points.

Modigliani and Sutch's approach was ingenious, but they themselves warned that, as with any policy counterfactual, one cannot control for factors occurring at the same time as the change in policy one wants to evaluate. The event study undertaken by Swanson provides, in principle, a solution to this problem. By focusing on the news- the unanticipated shock-one can solve the identification problem and avoid endogeneity issues. However, I see some problems with this approach. The first, already mentioned, is the fact that the effect of policy depends on expectations, which may be shaped by the state of the economy and other concurrent factors. In other words, event studies are not immune to the usual criticism that applies to reduced-form econometrics.

The second problem is more fundamental. The event-study methodology rests on two assumptions: that only unanticipated policy changes matter, and that the news of the policy change is immediately incorporated in prices and its effect is permanent. For example, the effect is measured by computing the cumulative response, summing across events, and this sum is interpreted as what the total effect of the policy would be if there were no future policy reversal. This is indeed reasonable if one assumes rational expectations and efficient markets, but these assumptions are particularly unrealistic in periods of financial disruption and in the presence of uncertainty about the policy transmission mechanism. In fact, if the efficient market hypothesis held, the event study would be appropriate, but then quantitative easing policies would be expected to have no effect. Standard finance theory says that in an efficient market, changes in the quantity of bonds purchased should not affect their prices.

Another problem is the possibility of delayed effects. The researcher conducting an event study faces a trade-off: the window must be narrow enough to avoid contamination from other factors but large enough to capture any delayed effect. Indeed, a lagged response is the explanation that Swanson gives for the lack of any substantial effects on corporate bond 
yields. To assess the possibility of lagged effects and reversals, one could try to use progressively larger windows, but here the difficulty is that there are only six announcements and they are quite close together.

Modigliani and Sutch's counterfactual exercise was perhaps naive, but it does provide information on effects that may occur with long lags. For what concerns the 10-year Treasury rate, however, this point is academic, since their empirical work and that by Swanson obtain roughly the same result. For corporate rates, on the other hand, it would be worth exploring whether a significant effect can be found using more standard macroeconomic tools, such as vector autoregression-based counterfactuals. This would also allow one to assess quantitatively the macroeconomic impact of Operation Twist.

LESSONS FROM THE ECB EXPERIENCE. An alternative way to manipulate an interest rate is simply to fix it. This is what the ECB did when, in response to the crisis, it introduced 1-year repo operations against a very broad range of collateral using a fixed-rate, full-allotment tender procedure (see Lenza and others 2010 for a discussion).

My figure 2 depicts ECB monetary policy operations from 2007 to the fall of 2010; the large scale of its 1-year long-term refinancing operations (LTRO) beginning in mid-2009 is evident. This experience with LTRO at a fixed rate makes for an interesting case study but has not received much attention in the U.S. literature. The 1-year rate is easier to control than the 10-year rate. In addition, with repos, the yield curve can be influenced without getting involved in potentially contentious relations with the Treasury. The question is whether by controlling the 1-year rate one is able to affect lending rates.

A counterfactual exercise in the spirit of Modigliani and Sutch shows that the effect has been significant (Giannone, Lenza, and Reichlin 2011). My figure 3 compares the realized path of 1-year corporate rates with a counterfactual path constructed as the expectation conditional on precrisis sample estimates and the postcrisis observed realization of business cycle variables. It shows that the realized path was significantly lower than the counterfactualan indication that the policy did work. Although one cannot clearly attribute the difference to LTRO, for the reasons discussed above, this result is nonetheless consistent with unpublished work at the ECB, based on a variety of methods, which suggests that the pass-through to rates on retail loans for the corporate sector has been broadly in line with historical regularities. ${ }^{1}$

1. However, the evidence on nonprice terms on loans from the bank lending survey is more mixed, with quite a lot of evidence that covenant and other credit terms tightened. 
Figure 2. Eurosystem Monetary Policy Operations, 2007-10

Billions of euros

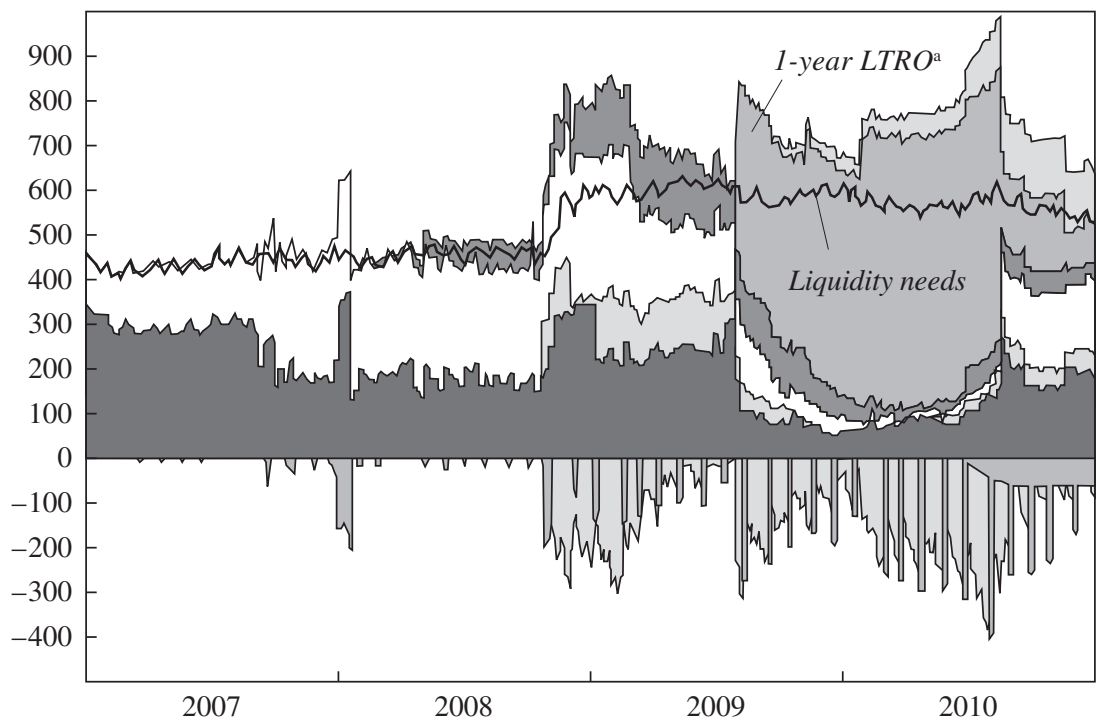

Source: European Central Bank.

a. $\mathrm{LTRO}=$ long-term refinancing operations.

Figure 3. Actual and Simulated Corporate Lending Rates, 2005-10

\section{Percent per year}

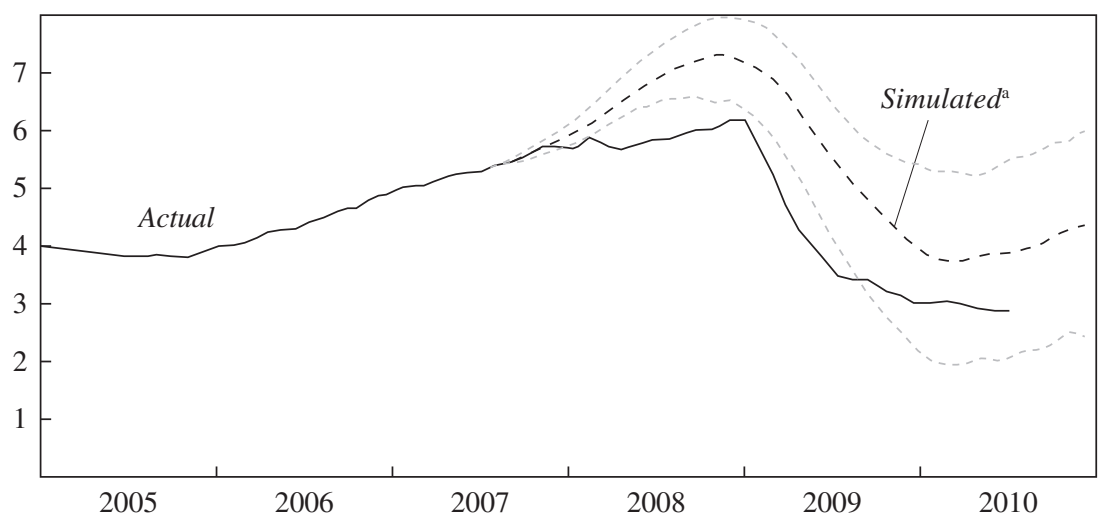

Sources: Bloomberg; author's simulations.

a. Simulation is based on the model of Giannone, Lenza, and Reichlin (2011). Dotted lines indicate 68 percent confidence intervals. 
It would be interesting to see whether a similar exercise analyzing corporate rates in the Operation Twist sample would provide similar evidence, since the event study fails to capture any substantial effect within the narrow window. Swanson seems to rule out this possibility and conjectures that the program had an effect only on those corporate securities that were good substitutes for long-term Treasuries.

CONCLUSIONS. This is a very nice paper. It is interesting that the result from Swanson's event study for the 10-year Treasury rate is in line with the results of the counterfactual analysis of Modigliani and Sutch (1967). This indicates that the result is robust to changes in methodology. The results regarding the transmission to other interest rates are less clear. Perhaps other tools, capable of measuring delayed effects of the policy, should be used to understand how the effect on long-term Treasury rates transmits to rates that are likely to affect private spending decisions. Given the magnitude of the estimated effects presented in this paper, it is likely that these effects will be close to zero. In general, much remains to be done to understand the transmission mechanism of quantitative easing. The analysis of historical cases such as that in this paper, as well as of the experience of other countries, is the way to go.

\section{REFERENCES FOR THE REICHLIN COMMENT}

Bernanke, Ben S. 2009. "The Crisis and the Policy Response." Stamp lecture, London School of Economics, January 13. . 2010. "The Economic Outlook and Monetary Policy." Presented at the Federal Reserve Bank of Kansas City Economic Symposium, Jackson Hole, Wyo., August 27.

Bullard, James. 2010. "Qe2 in Five Easy Pieces." Presented at the meeting of the New York Society of Security Analysts, New York, November 8.

Giannone, Domenico, Michele Lenza, and Lucrezia Reichlin. 2011. "Money, Credit and the Business Cycle under 'Normal' and 'Exceptional' Circumstances: Euro Area Evidence." Université Libre de Bruxelles and London Business School (January).

Lenza, Michele, Huw Pill, and Lucrezia Reichlin. 2010. "Monetary Policy in Exceptional Times." Economic Policy 25: 295-339.

Modigliani, Franco, and Richard Sutch. 1967. "Debt Management and the Term Structure of Interest Rates: An Empirical Analysis of Recent Experience." Journal of Political Economy 75: 569-89.

Woodford, Michael. 2011. "Quantitative Easing and Credit Easing: When Are 'Unconventional' Policies Needed?' Duisenberg Lecture, Duisenberg School of Finance, Amsterdam, January 11. 


\section{COMMENT BY}

JONATHAN H. WRIGHT This imaginative and innovative paper by Eric Swanson applies an event-study methodology to a question that is nearly half a century old: the effect of Operation Twist on Treasury yields. Identifying the effects of Operation Twist is complicated because other factors (such as issuance of new Treasury securities) were having an impact around the same time. An event-study approach using daily data is an ideal strategy to resolve this problem and to attempt to isolate the pure effect of the announcement of Operation Twist. The conventional wisdom is that Operation Twist was a small operation that had little or no effect on yields. This paper argues convincingly that this is not quite right. Operation Twist was a sizable program, relative to the size of the economy at that time, and its announcement lowered yields by about 15 basis points-a statistically significant effect, although not very large. With the U.S. economy today still facing considerable slack, and monetary policy stuck at the zero lower bound, reexamination of this earlier experience with policies to alter the configuration of interest rates is very timely.

COMPARING OPERATION TWIST AND QE2. The paper compares different authors' estimates of the impacts of changes in the effective supply of Treasury securities on yields. Most of the time in empirical macroeconomics, researchers have a hard time agreeing on the sign of an effect, let alone its magnitude. From this perspective, the work on the changing supply of Treasuries is a model of unanimity: the demand curve for Treasuries slopes down. Federal Reserve purchases of $\$ 600$ billion in Treasury securities raise their price and lower their yields by an amount that varies, according to the study, from about 15 to 50 basis points. The study by Stefania D'Amico and Thomas King (2010) is a bit of an outlier in implying a bigger number: 100 basis points. Still, by the dismal standards of the profession, this amounts to a remarkable degree of consensus. How persistent these effects are is of course another question.

The difficulty is in knowing why Treasury purchases lower yields. Within the paradigm of finance theory, these effects should be negligible. Operation Twist and today's quantitative easing are small programs relative to the Treasury market, and of trivial magnitude relative to the global fixedincome market. Nonetheless, empirically, it seems quite clear that they did have measurable impacts on Treasury yields. The paper discusses some plausible explanations. One is that such operations lower the net supply of long-term Treasury securities in the market, driving down their yields in the presence of preferred-habitat investors in a segmented market (Vayanos and Vila 2009). Another is that these operations have some signaling effect. 
There are several possible variants on this theme. For example, the recent quantitative easing program might have convinced investors that the Federal Reserve is determined to keep policy accommodative for longer, lowering the expected path of rates. Or, by lowering investors' perceived odds of a sharp tightening in monetary policy, it could have had a separate effect of reducing risk premia. ${ }^{1}$ Or there could be some story involving multiple equilibria: a good equilibrium in which the economy bounces back reasonably quickly and real risk premia are low, and a bad equilibrium in which the economy remains stuck in a long period of weak performance and real risk premia remain high. In such a story, quantitative easing may help the economy coordinate on the good equilibrium. This kind of story seems particularly germane to the so-called QE1 operation, which involved restarting frozen mortgage and commercial paper markets, but it may help explain the effects of recent Treasury purchases as well.

TREASURY ISSUANCE. In the segmented-markets view (Vayanos and Vila 2009), as already mentioned, QE2 worked through the channel of altering the net supply of long-term Treasuries in the market. Any other change in net supply would have exactly the same effect. But in the last few years, quantitative easing has been only the second-largest driver of effective Treasury supply. The largest has been Treasury issuance and the change in the maturity distribution of that issuance, as noted in the paper. My figure 1 shows the supply of Treasury debt of maturity greater than 2.5 years in the hands of the public, from the dataset of James Hamilton and Jing $\mathrm{Wu}$ (forthcoming). ${ }^{2}$ It has ballooned by nearly $\$ 2$ trillion since the onset of the financial crisis. This dwarfs QE2.

If one takes increased Treasury issuance as effectively equivalent to a decrease in Federal Reserve purchases (that is, if all that matters is the supply of Treasuries available to the broader public), then Swanson's estimates from Operation Twist would imply that this issuance has raised 10-year Treasury yields by about 50 basis points. And remember that Swanson's estimates of the effects of Treasury purchases are on the low end. Moreover, going forward, the supply of long-term Treasury debt is firmly on a skyward trajectory. Yet at the time of writing in the spring of 2011, 5- and 10-year Treasury yields are around 2 percent and $3 \frac{1}{2}$ percent, respectively. If one

1. If, after engaging in quantitative easing, the Federal Reserve were to wish to tighten monetary policy sharply, then losses on asset sales or interest on reserves would lower the seignorage payments made to the Treasury, perhaps substantially. In that case quantitative easing can be thought of as representing a commitment not to raise rates too fast.

2. I focus on maturities exceeding 2.5 years because that is the shortest maturity that was bought in substantial quantity in the QE2 program. 
Figure 1. Treasury Debt Held by the Public with Maturity Exceeding 2.5 Years, 1990-2011

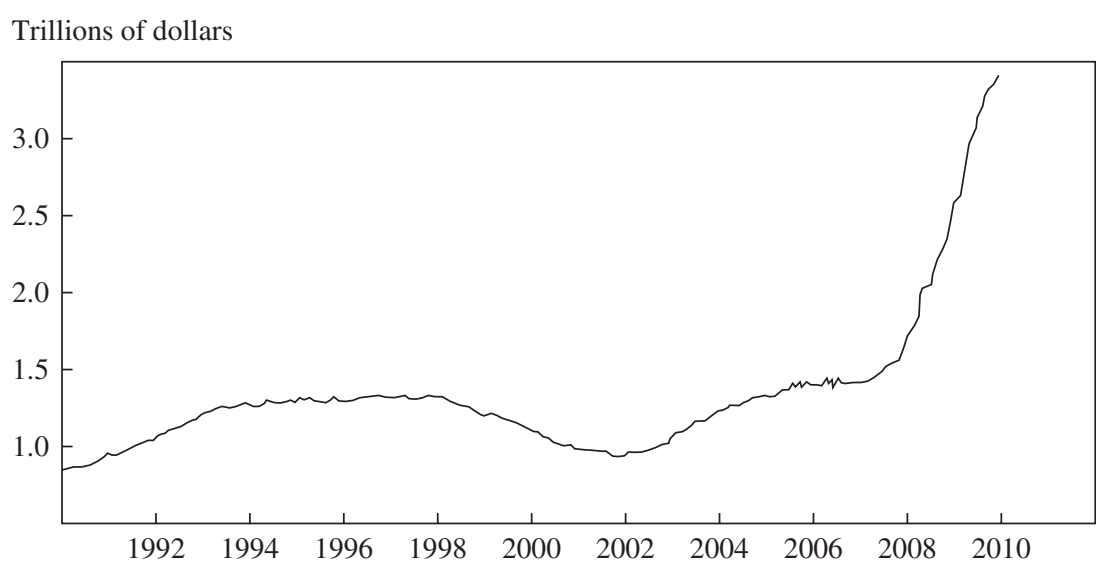

Source: Hamilton and Wu (2010).

supposes that these yields are being substantially elevated by the current and prospective future supply of longer-term Treasury securities, this raises a huge puzzle of why long-term Treasury yields remain so low. However, if one believes that quantitative easing operates through some signaling channel, rather than just its effect on the stock of Treasury debt in the market, then the puzzle is resolved, as there is then no reason to think that Treasury issuance and Federal Reserve purchases must have opposite effects of equal magnitude. Nor, by the same logic, is there any reason to assume that possible Federal Reserve sales of Treasury securities in the future will necessarily cause yields to rise by as much as the QE2 purchases caused them to fall.

QE2 AND AGGREGATE DEMAND. As already noted, there is broad agreement that QE2 lowered 10-year Treasury yields. Perhaps a midpoint of the estimates of the effects is 25 basis points. Ultimately, what matters most is the effect of these Treasury purchases on aggregate demand. This means that the effect has to pass through to the interest rates that are relevant to the spending decisions of households and businesses, and it has to be at least somewhat persistent. Swanson finds that Operation Twist had only tiny effects on corporate yields. In contrast, Arvind Krishnamurthy and Annette Vissing-Jorgensen (2011) find that QE2 lowered interest rates on high-grade corporate debt by about as much as on Treasuries but had smaller effects on riskier corporate yields. Conceivably, by raising inflation expectations, QE2 might have lowered real private borrowing costs a bit 
more. All in all, it seems likely that QE2 nudged up both economic activity and inflation at a time when both were too low. But it is hard to see how the effect of QE2 on the configuration of interest rates was large enough to provide substantial support to aggregate demand, unless one appeals to some particularly large nonlinearity.

A simulation by Hess Chung and others (2011) using the Federal Reserve's FRB/US model suggests that QE2 will expand employment in 2012 by about 700,000. ${ }^{3}$ This simulation assumes that QE2 lowered Treasury term premia by 25 basis points but had no direct effect on spreads of corporate and mortgage rates over their Treasury counterparts. ${ }^{4}$ Meanwhile, in FRB/ US, the stronger economic outlook induced by lower term premia endogenously causes corporate and mortgage rates to fall by more than the drop in Treasury yields. In contrast, according to the event-study evidence reported in both Swanson's paper and Krishnamurthy and Vissing-Jorgensen (2011), Federal Reserve purchases of Treasuries led private sector rates to fall by less than Treasury yields. Since it is private sector rates that matter for aggregate demand, this would suggest that the estimates of Chung and his coauthors represent an upper bound on what QE2 could have done. And even so, a boost of 700,000 to employment, although welcome, represents a very small part of the slack in labor markets and leaves the economy far from being in danger of overheating. Overall, my reading of the evidence is that QE2 helped the Federal Reserve move closer to its employment and inflation objectives but was too timid (or politically constrained) given the extent of the shortfall in aggregate demand.

ANOTHER KIND OF QUANTITATIVE EASING. Swanson has written a fine analysis of the historical evidence on the efficacy of a program that was designed to influence the configuration of interest rates. But there is another, earlier precedent for today's quantitative easing, dating from 1942 to 1951, when the Federal Reserve capped the yields of longer-term Treasury bonds. In other words, the Fed set the price of bonds, not the quantity that it was going to buy. This episode, documented by Barry Eichengreen and Peter Garber (1991) and Mark Toma (1992), is very relevant because one alternative to QE2 would have been to target, say, the 5-year Treasury yield. In the 1942-51 operation, the Federal Reserve succeeded in keeping long-term rates stable and just below the cap. Although it had to substantially tilt

3. I am referring here to the incremental effect of QE2, rather than the combined effect of all of the Federal Reserve's unconventional policies over the last few years.

4. I am grateful to Jean-Philippe Laforte of the Federal Reserve Board for clarifying this aspect of the FRB/US simulation to me. 
the maturity composition of its portfolio toward long-term securities, at no point did it hold more than 13 percent of U.S. government securities with maturities greater than 10 years (Toma 1992). It would be interesting to compare this policy and Operation Twist more carefully. But it may well be that the act of credibly committing to a set yield got rational expectations working on the Federal Reserve's side, thereby giving it more traction over long-term yields. ${ }^{5}$ Another, more contemporary example is Switzerland, which today operates monetary policy by targeting the 3-month interest rate. This is of course only a slightly longer-maturity interest rate than used by other central banks, but it seems to pose no great difficulty for the Swiss National Bank.

CONCLUSIONS. This paper corrects and adds to our understanding of Operation Twist. At the time of writing, pessimists think that the U.S. economy faces an extended period in which unemployment will remain too high and inflation too low. If they turn out to be correct, then the Federal Reserve's mandate will call for further quantitative easing, perhaps adjusted in ways to make it more potent, such as buying longer-duration Treasuries or directly targeting 5-year Treasury yields. Others anticipate that the rebound will be so strong that the Federal Reserve will need to contemplate asset sales before long. Either way, careful analysis of the limited historical experience of the effects of policies to manipulate the maturity structure of outstanding debt is important.

\section{REFERENCES FOR THE WRIGHT COMMENT}

Chung, Hess, Jean-Philippe Laforte, David Reifschneider, and John C. Williams. 2011. "Have We Underestimated the Likelihood and Severity of Zero Lower Bound Events?" Working Paper no. 2011-01. Federal Reserve Bank of San Francisco.

D'Amico, Stefania, and Thomas B. King. 2010. "Flow and Stock Effects of LargeScale Treasury Purchases." Finance and Economics Discussion Series 2010-52. Washington: Federal Reserve Board.

Eichengreen, Barry, and Peter M. Garber. 1991. "Before the Accord: U.S. MonetaryFinancial Policy, 1945-51." In Financial Markets and Financial Crises, edited by R. Glenn Hubbard. University of Chicago Press.

5. Of course, this set to one side the macroeconomic consequences of keeping interest rates at these levels, and that is why the policy was abandoned in the Treasury-Federal Reserve accord of 1951. But as long as inflation remains unacceptably low and unemployment unacceptably high, the only macroeconomic consequences of capping long-term interest rates are desirable ones. 
Hamilton, James D., and Jing Cynthia Wu. Forthcoming. "The Effectiveness of Alternative Monetary Policy Tools in a Zero Lower Bound Environment." Journal of Money, Credit, and Banking.

Krishnamurthy, Arvind, and Annette Vissing-Jorgensen. 2011. "The Effects of Quantitative Easing on Interest Rates.” Northwestern University.

Toma, Mark. 1992. "Interest Rate Controls: The United States in the 1940s." Journal of Economic History 52, no. 3: 631-50.

Vayanos, Dimitri, and Jean-Luc Vila. 2009. "A Preferred-Habitat Model of the Term Structure of Interest Rates." Working Paper no. 15487. Cambridge, Mass.: National Bureau of Economic Research.

GENERAL DISCUSSION Olivier Blanchard suggested that looking at capital flows might provide useful information about the way QE2 had worked. He found it striking that almost as soon as QE2 was implemented, net capital flows to emerging economies actually decreased, and indeed they turned negative in some countries. That did not fit the standard story. Perhaps the explanation was that once the Federal Reserve had made it clear that it would do "whatever it takes" to prevent deflation in the United States, investors became more optimistic about U.S. economic prospects. If so, this was an important channel through which QE2 might have affected the US economy.

David Romer recounted a recent conversation he had had with Robert Solow, who had been a senior economist at the Council of Economic Advisers at the time of Operation Twist. Solow recalled, with some annoyance, that even as the Treasury and the Federal Reserve were working to reduce long-term interest rates, some government-sponsored agencies were taking advantage of the situation to issue debt at the lower rates, thus undoing, in Solow's view, much of what the operation had sought to accomplish.

Romer also questioned the notion, which the discussion thus far seemed to take for granted, that Operation Twist was not intended to have a signaling effect. When the newly elected president of the United States goes personally to the White House briefing room and announces a set of economic policies, one of which is Operation Twist, and this is followed by the Federal Reserve declaring its complete support, it seemed to Romer far from obvious that expectations about the path of the federal funds rate would not be affected. Indeed, he thought that not just the dollar amounts of both Operation Twist and QE2 but also their signaling impact were of first-order importance.

Laurence Ball agreed with Jonathan Wright that the economic impact of a 15-basis-point change in interest rates would be small. Operation Twist 
might have been large enough to affect gold flows, but it seemed too small to have impacted aggregate demand. In terms of today's economy, it might take $\$ 6$ trillion worth of quantitative easing, assuming the Federal Reserve could find enough securities to buy, to reduce interest rates enough to measurably affect the economy, if the relationship is linear, and QE2 was of nowhere near that magnitude. That, incidentally, was why the claims one heard today that QE2 was somehow going to cause runaway inflation were laughable, in Ball's view.

Justin Wolfers objected that, as Swanson himself had shown, the effect of a 100-basis-point shock to the federal funds rate is to move rates at the long end of the yield curve by about 15 basis points, and few economists think of a 100-basis-point shock as small. And the conventional view is that most of the economic effect of a federal funds rate intervention is through long-term rates, which are what matter for businesses' borrowing decisions.

Christopher Sims reminded the Panel that the effect of Operation Twist, as Swanson had shown, had been to raise short-term rates and lower long-term rates by about the same amount. It was not at all clear to him that that was equivalent in its impact to simply moving the short-term rate up by itself.

Laurence Ball also pointed out that the one-day effect of an intervention like Operation Twist could well be larger than the one-week or the one-month effect, because of institutional features in the markets that give rise to temporary mispricings, which are quickly arbitraged away. For him this raised questions about whether the estimated one-day effect was a reliable measure of the impact. On the issue of signaling effects, Ball wondered, more than half seriously, whether QE2 was meant in part to rattle the cages of the inflation hawks and the editorial page of the Wall Street Journal, to signal that the Federal Reserve would not be cowed by their criticism. Even if QE2 itself was of little real importance, using it to send a message about the Fed's willingness to ignore the hawks could prove valuable in the future.

Gerald Cohen argued that even though QE2 had had little change on nominal yields, real yields had declined substantially, to minus 50 or 60 basis points on the five-year note. At the same time there was an offsetting increase in inflation expectations.

Jeremy Nalewaik suggested that looking at equity prices around the event windows might help differentiate between the stories being offered. If the preferred-habitat story were closer to the truth, then one might expect to see little impact on equity prices. As it happened, a fairly strong stock market rally occurred around the time the Federal Reserve started to drop 
hints about QE2, and indeed some of the Fed governors have claimed at least partial credit for some of that run-up.

Richard Cooper, who like Robert Solow had been present at the creation of Operation Twist, emphasized that it had been designed as a response to what the new administration saw as a dilemma between international and domestic economic policy. President Kennedy was deeply concerned about the "gold problem," the continuing outflow of gold from the Treasury at the low dollar price at which it was then fixed. However, the Council of Economic Advisers was strongly opposed to raising interest rates, fearing that it would weaken an already lukewarm economy. Operation Twist seemed like an ingenious compromise between these two views. Short-term rates would be raised to help with the international situation, because higher short-term rates would help support the dollar, and long-term rates would be lowered to improve the domestic situation, because those were what mattered for domestic business activity. It was a carefully crafted strategy, and for that reason Council member James Tobin became furious upon learning shortly thereafter that the Treasury was auctioning five-year notes-a move that seemed to undercut the whole enterprise.

Cooper also agreed with Sims that one should measure the impact of the operation in terms of the change in the relationship between short-term and long-term rates, not by the effect on either alone. By that measure the impact was on the order of 30 basis points rather than 15 , because as the paper showed, short-term rates rose by about as much as long-term rates fell.

Ricardo Reis suggested that an important difference between Operation Twist and QE2 was that in the former the Federal Reserve and the Treasury were working in the same direction, whereas in the latter they are working in completely opposite directions. That being the case, Reis argued, it would be interesting, and not very difficult, to construct an integrated budget for the government including the Federal Reserve, simply combining their balance sheets to see whether the net supply of Treasury securities in the hands of the public rose or fell.

Moreover, Reis suggested, if one were to adopt that approach, then the historical record provides an abundance of natural experiments on the effectiveness of monetary policy. The Treasury has frequently altered the maturity structure of its issues in different ways over the past 50 years. These frequent smaller changes in policy direction constitute a wealth of mini-Twists or mini-QE2s that could be usefully analyzed for their impact.

Finally, on the question of whether a 15- or a 30-basis-point change in interest rates was small or large, Reis reminded the Panel, somewhat tongue in cheek, that some observers were of the opinion that by keeping 
the federal funds rate a mere 50 or 100 basis points too low for less than two years, the Federal Reserve had brought on the worst economic downturn since the Great Depression.

Donald Kohn reported on a recent conversation with someone who had been on the Federal Reserve staff at the time of Operation Twist. The former staff member said that the Fed at that time was not targeting the federal funds rate but rather had a free reserves target, which was expected to affect short-term interest rates but not directly. The former staffer also said that the Federal Reserve was supportive of the administration's desire to raise the Treasury bill rate in order to slow gold outflows. It was no accident, in the staffer's view, that Treasury bill rates did rise, and that was considered a success of the program at the time. The staffer also commented that it was private corporations rather than the government agencies that took advantage of the lower long-term rates under Operation Twist, which was part of its intention, so that from that perspective as well the program had enjoyed some success.

Kohn also raised the issue of whether it mattered how a policy of quantitative easing was implemented: was allowing the purchase of Treasury securities to show through to an increase in reserves more effective than if the reserves were absorbed, say, by doing reverse repos? He suspected that adding reserves reinforced the signaling effect, because it communicated that rates would be held lower for a longer period and because some might see it as suggesting that inflation would be higher in the future. Kohn saw the recovery in inflation expectations in the fall of 2010 as possibly due in part to the Fed's reserves policy, and thus as a success of the program.

Robert Hall commented that Cooper's remarks reflected the collective wisdom of macroeconomists that it is the long-term interest rate that belongs in the Hicksian IS curve. Hall himself, however, had demonstrated theoretically, in a Brookings Paper from the 1970s, that it is the short-term rate that actually matters. Although the long-term rate does matter to businesses deciding whether or not to undertake an investment project, the aggregate investment function is essentially about timing: is it better to do the project now or later? And it turns out that when one takes first differences of interest rates, what one is left with is the short-term rate. That implied that to the extent it raised short-term rates, Operation Twist was actually contractionary.

Benjamin Friedman said he had long been troubled by discussions of Operation Twist, including this one, because the underlying presumption seemed to be that in a perfect world such a stratagem should not work, and therefore any observed effects must be due to some kind of ad hockery or institutional feature or behaviorial quirk. That view in turn derived from 
the theoretical presumption that all nonmoney assets are somehow perfect substitutes. In Friedman's view there was no reason to think that all nonmoney assets should be perfect substitutes, or even that Treasury securities of differing maturities should be perfect substitutes. Long-term and shortterm Treasuries have very different risk properties, and if one accepts, uncontroversially these days, that the marginal investor is risk averse, it follows from that alone that they are not perfect substitutes. That being the case, the standard presumption should be that changes in the relative quantities of these different securities in the market will result in changes in their relative market-clearing returns. An implication of that argument was that Cooper was right in saying that Operation Twist's impact should be measured not as the change in short-term or long-term interest rates alone, but rather as the change in one relative to the other.

Another implication, Friedman continued, was that one ought to look not only at the prices of securities but also at quantities transacted. After all, when monetary policymakers accompany their policy actions with announcements, what is announced is typically some quantity or some change in relative quantities. This was important in the case of Operation Twist, Friedman argued, because of what was happening in the background at the time. From the end of World War II until the early 1970s, the mean maturity of the public debt outstanding fell from more than 10 years to around $2 \frac{1}{2}$ years. The effect of Operation Twist was in the same direction, reducing debt at the long end of the yield curve while increasing it at the short end. That means that in order to have an impact, Operation Twist had to shorten average maturities by an amount over and above the background trend. Friedman pointed out that maturities actually went in the wrong direction during a key part of the operation: they rose for a while in the spring of 1961. That happened because, as others had noted, the Treasury failed to stick to the policy but instead issued new five-year notes in the middle of the operation. Friedman therefore agreed with Jonathan Wright that Operation Twist didn't work because it wasn't tried. He also suggested that although Swanson's paper was clear in stating that it was investigating the announcement effect of Operation Twist, one should explicitly distinguish that from the policy effect- the actual change in quantities of securities outstanding — which in the specific case under discussion did not materialize.

Following on Hall's comment, Christopher Sims remarked that to engineer a rise in short-term rates and simultaneously a fall in long-term rates amounts to saying to potential investors that they should postpone investment because they will get a better financing deal later. 
Sims also commented on the paper's claim that the Operation Twist period was a good one to study because, unlike today, foreigners did not hold a large fraction of the national debt. That was true in a sense, but if one is talking about preferred-habitat theory, the agents populating the markets are critical in determining what the effects will be. Today foreign institutions do hold much of the U.S. public debt, and so any lessons from Operation Twist may be of less relevance.

Finally, responding to Friedman, Sims suggested that there is a basis for thinking that, absent market imperfections like preferred habitats, an intervention like Operation Twist should have no effect. That basis is the Modigliani-Miller theorem, which holds that a firm cannot raise its net value by changing the average maturity of its debt. The idea here was that, similarly, changing the debt structure of the federal government cannot have real effects, unless fiscal policy is also changing or unless, again, there is some market imperfection. Friedman countered that Modigliani-Miller was about the aggregate of a firm's securities outstanding, which remains unchanged when the firm adjusts the term structure of its debt. ModiglianiMiller says nothing about whether issuing securities of one maturity rather than another affects their relative pricing, and it is that change in pricing that can have real effects on the economy.

Joseph Gagnon followed up on Lucrezia Reichlin's point that the real effects of an announced change in policy must be permanent, or at least fairly long lasting, if there is to be an announcement effect. His own work had found that the market interest rates on Treasury securities were cointegrated with bond yields, confirming a permanent effect. Yet Wright had spoken at some length about temporary effects, and Wright's own work as well as work by James Hamilton had found temporary effects. Gagnon therefore wondered whether Wright believed that the effects of QE2 are mainly permanent, as Gagnon himself thought they must be, or temporary.

Gagnon also cited a paper by Robert McCauley and Kazuo Ueda on an attempt at quantitative easing by the Bank of Japan. That paper found that the central bank's net new purchases of bonds had an average maturity of just one year, indicating that this was again a case of a policy that did not work because it was not really tried.

William Brainard remarked that financial economists of his acquaintance regarded the expectations hypothesis of the term structure, which assumes that securities of different maturities are perfect substitutes, as one of the most clearly rejected hypotheses in that field.

Brainard also returned to the point that there had been endogenous responses to Operation Twist by issuers of debt other than the Treasury. 
These complicate the analysis because, on the one hand, such responses might be precisely part of the objective, but on the other hand they dampen the initial effect. Although it would be difficult to do in an event study, one would like to know where the response is coming from, what the quantities of new issues are, and what are the explanations for the differences in response. From that perspective, Brainard continued, one has to wonder whether the short horizon on which the paper focuses is the relevant one. It is unlikely that, for example, state and local policymakers will respond to an intervention like Operation Twist within a two-day window. If one thinks the true effect occurs over a somewhat longer run, then a longer sample period is needed.

Responding to Hall, Brainard maintained that a firm contemplating an irreversible investment in physical capital does have to consider the cost of financing it over the project's lifetime, not just what the short-term interest rate is at the outset. Although Hall's theorem was surely correct given his assumptions, as soon as one introduces risk and the irreversibility of the physical investment, those assumptions are no longer relevant. Hall replied that an unambiguous implication of standard finance theory was that the composition of an issuer's securities cannot affect the prices of those securities because they are only repackaging the underlying risks. Gauti Eggertsson and Michael Woodford's 2003 Brookings Paper explained this very clearly. To claim otherwise, Hall argued, is not consistent with modern financial theory.

Justin Wolfers wondered whether anyone on the Panel could explain why the Federal Reserve chooses to announce the quantities of securities it intends to buy or sell rather than the effects on interest rates it is trying to achieve. Although there are plenty of clever analysts who can calculate the demand elasticities and back out the implied interest rate targets, there seemed to Wolfers to be no reason not to announce them directly. 
